\title{
Fifteen-Year Exposure Test of Porcelain Enamels
}

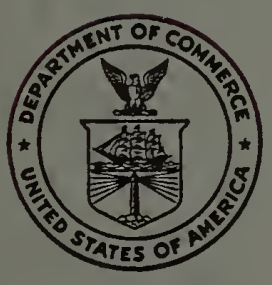

United States Department of Commerce

National Bureau of Standards

Building Materials and Structures Report 148 


\section{BUILDING MATERIALS AND STRUCTURES REPORTS}

On request, the Superintendent of Documents, U. S. Government Printing Office, Washington $25, \mathrm{D}$. C., will place your name on a special mailing list to receive notices of new reports in this series as soon as they are issued. There will be no charge for receiving such notices.

If 100 copies or more of any report are ordered at one time, a discount of 25 percent is allowed Send all orders and remittances to the Superintendent of Documents, U. S. Government Printing O.fice, Washington $25, D$. C.

The following publications in this series are available by purchase from the Superintendent of Documents at the prices indicated:

BMS1

BMS2

BMS3

BMS4

BMS5

BMS6

BMS7

BMS8

BMS9

BMS10

BMS11

BMS12

BMS13

BMS14

BMS15

BMS16

BMS17

BMS18

BMS19

BMS20

BMS21

BMS22

BMS23

BMS24

BMS25

BMS26

BMS27

BMS28

BMS29

BMS30

BMS31

BMS32

BMS33

BMS34

BMS35

BMS36

Research on Building Materials and Structures for Use in Low-Cost Housing --..--.Methods of Determining the Structural Properties of Low-Cost House Constructions.Suitability of Fiber Insulating Lath as a Plaster Base-_._. Accelerated Aging of Fiber Building Boards Structural Properties of Six Masonry Wall Construetions. Survey of Roofing Materials in the Southeastern States Water Permeability of Masonry Walls Methods of Investigation of Surface Treatment for Corrosion Protection of Steel-Structural Properties of the Insulated Steel Construction Co.'s "Frameless-Steel" Constructions for Walls, Partitions, Floors, and Roofs Structural Properties of One of the "Keystone Beam Steel Floor" Constructions Sponsored by the H. H. Robertson Co
Structural Properties of the Curren Fabrihome Corporation's "Fabrihome" Constructions for Walls and Partitions
Structural Properties of "Steelox" Constructions for Walls, Partitions, Floors, and Roofs, Sponsored by Steel Buildings, Inc Properties of Some Fiber Building Boards of Current Manufacture Indentation and Recovery of Low-Cost Floor Coveringsby the Wheeling Corrugating $\mathrm{Co}_{-}$ Structural Properties of a "Tilecrete" Floor Construction Sponsored by Tilecrete Floors, Ine Sound Insulation of Wall and Floor, Constructions "ProStructural Properties of "Pre-fab" Construetion for Walls, Partitions, and Floors Sponsored by Harnischfeger Corporation........ Preparation and Revision of Building Codes... Struetural Properties of "Twachtman" Constructions for Walls and Floors Sponsored by Conneeticut Pre-Cast Buildings Corporation .

Structural Properties of a Concrete-Block Cavity-Wall Construction Sponsored by the National Concrete Masonry Association.

Structural Properties of "Dun-Ti-Stone" Wall Construction Sponsored by the W. E. Dunn Manufacturing Co

Structural Properties of a Brick Cavity-Wall Construction Sponsored by the Brick Manufacturers Association of New York, Inc-. Structural Properties of a Reinforced-Brick Wall Construction and a Brick-Tile CavityWall Construction Sponsored by the Structural Clay Products Institute Structural Properties of Conventional Wood-Frame Constructions for Walls, Partitions,

Floors, and Roofs
Structural Properties of "Nelson Pre-Cast Concrete Foundation" Wall Construction Sponsored by the Nelson Cement Stone Co., Ine
Structural Properties of "Bender Steel Home" Wall Construction Sponsored by the Bender Body Co

Backflow Prevention in Over-Rim Water Supplies

Survey of Roofing Materials in the Northeastern States.-

Structural Properties of a Wood-Frame Wall Construction Sponsored by the Douglas Fir Plywood Association ..........

Structural Properties of "Insulite" Wall and "Insulite" Partition Constructions Sponsored by The Insulite Co .........

Structural Properties of Two Brick-Concrete-Block Wall Constructions and a ConcreteBlock Wall Construction Sponsored by the National Conerete Masonry Association - Wall Const

Plastic Calking Materials Performance Test of Floor Coverings for Use in $\mathrm{Low}-\mathrm{Cost}$ Housing: Part 1 Stability of Sheathing Papers as Determined by Accelerated Aging. Part 1.-.-Structural Properties of Wood-Frame Wall, Partition, Floor, and Roof Constructions With "Red Stripe" Lath Sponsored by The Weston Paper and Manufacturing Co..

Out of print

tSuperseded by BMS144.

†Superseded by BMS116.

[List continued on cover page III] 


\title{
Fifteen-Year Exposure Test of Porcelain Enamels
}

\author{
Dwight G. Noore and William N. Harrison
}

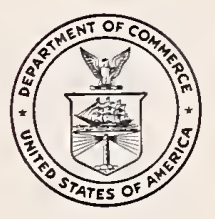

Building Materials and Structures Report 148

Issued June 28, 1957 


\section{Contents}

1. Introduction

2. Types and sources of enamels

3. Description of panels, method of mounting, and reather conditions at

4. Results

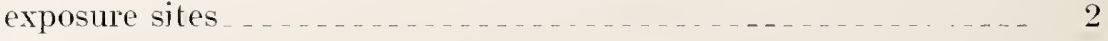

4.2. Corrosion protection . _ _ _ _ _ _ _ _ _ _... 3

4.3. Gloss measurements _.

4.4. Color-difference measurements _....... 8

4.5. Microstructure of surfaces____ 8

5. Effect of variation in weather conditions at four exposure sites _... 8

6. Laboratory tests for predicting weather resistance 10

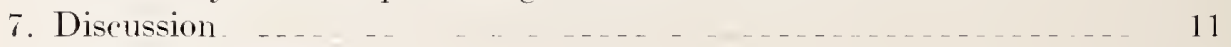

8. Recommendations _

9. Summary _

10. References 


\title{
Fifteen-Year Exposure Test of Porcelain Enamels
}

\author{
Dwight G. Moore and William N. Harrison
}

\begin{abstract}
The weather resistance of 768 panels representing 14 types of enamel was evaluated after 15 years of exposure at Washington, D. C., St. Louis, Mo., Lakeland, Fla, and A tlantic: Cit $y, X^{2} . J$. Changes in oloss and color were taken as criteria of weather resistance. A direct relation existed between acid resistance and weather resistance, except that a few of the red enamels of good acid resistance showed a pronounced fading after exposire. A modified acid-resistance test was devised that separated red enamels that showed pronounced fading from those that were highly resistant to color change.

The ease of cleaning was related to the weather resistance, the enamels that lost most of their initial gloss on weathering being more difficult to clean than those that showed high gloss retention. All of the enamels protected the steel from corrosion when initial coverage was complete.

Except for a relatively few enamels, variations in climate at the four exposure sites had only a minor effect on their weathering behavior.
\end{abstract}

\section{In troduction}

Porcelain enamel is being used in increasing volume as an exterior finish for such structures as office buildings, store fronts, and gasoline filling stations $[1,2] *$ Curtain-wall construction methods together with the emphasis on color in modern architecture have helped to popularize this particular finish. In fact, probably because of this trend toward color, porcelain enamel has been userl to a greater extent than either stainless steel or aluminum as an exterior facing for buildings [2]. The relative ease of decontaninating an enamel surface in case of atomic attack is an additional consideration in some types of structures [1].

Another reason for the increasing use of porcelain enamel is the excellent resistance to weathering shown by some of the early installations. For example, there are reliable reports of street and advertising signs and of building fronts, that have been installed for $25 \mathrm{rr}$ and longer without noticeable deterioration. On the other hand, there have been occasional installations where both the gloss and color of the finish have changed appreciably in as short a time as $10 \mathrm{yr}$. To prerent future installations of enamels of poor resistance, it is desirable to have data on the weather resistance of various enamel types and it is also important to devise a test that will indicate weather resistance.

A test to obtain such information was begun by the National Bureau of Standards in 1940. A total of 864 panels, $1 \mathrm{ft}$ square, and an equal number of 4-by 6-in. laboratory specimens, were prepared by 12 cooperating manufacturers. Of the 864 large panels, 768 were exposed and 96 were placed in storage for use as reference stantards. The base metal in each case was enameling' iron. The exposure sites selected were Washington, D. C., St. Louis, Mo., Lakeland, Fla., and Atlantic City, N. J.

Fourteen types of enamel were included. Thesc trpes represented enamels that were in common use from 1930 to 1940 . Shortly after Workl War II, enamels opacified with titanium dioxicle

*Figures in brackets indicate the literature references at the end of this eport. came into widespread use for white and paste. finishes. These enamels are considerably different from the acid-resistant white and buff compositions included in the present investigation. However, because one of the principal objectives of sturty was to correlate weather resistance with some more easily measured property of the enamel finish, the obsolescence of some of the compositions does not necessarily detract from the ralue of the data.

The present paper constitutes the third progress report of the investigation. The first report was published in 1942 [3] and the second in 1949 [4]. It was originally intended that the test would be terminated after $15 \mathrm{rr}$, but, because many of the enamels showed only a minor deterioration after this testing period, it was decided to expose the Washington panels until a testing time of possibly 25 or $30 \mathrm{rr}$ had been accumulated. However, mostly because of difficulties in providing proper maintenance, the panels from Lakeland, St. Louis, and Atlantic City were returned to Washington and the testing at these locations was terminated.

\section{Types and Sources of Enamel}

The enameled panels were supplied by the 12 cooperating companies who were active in the field of architectural enamels in 1939. The frits' and various mill additions ${ }^{2}$ for preparing the enamels were supplied by 4 frit companies. Finch of these 4 companies furnisher the mitcrials for each of the 14 enamel types to 1 or 2 of the 1 ? different fabricators, who then applied the entme to the specimens. By this alrangentemt, it wats possible to introduce the two villiables of frit source and fabricator. The frits were all proprietary products for which no chemical amalyses were available. It is probable that there were at least minor variations in composition for any 1 emamed type as supplied by the t fit compan nies.

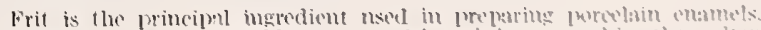
It is formed by melt ing sutable raw materinls and then quenching the molsen mass, usmally by pomritu imto cold water.

mass, mathe by pomrite into cold water.

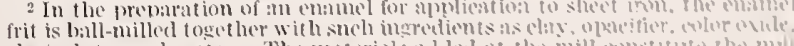

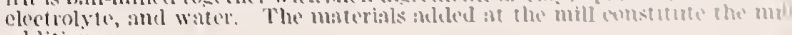
atditions.
} 
Likewise, each fabricator produced an enamel of slightly different properties from the same frit because of minor variations in the mill batch, the milling procedure, and the firing conditions. Thus, although the inrestigation included nominally only 14 types, there were, in effect, 96 enainels under study.

\section{Description of Panels, Method of Mounting, and Weather Condi- tions at Exposure Sites}

The panels, which were $1 \mathrm{ft}$ square, were fabricated of 16-gage iron and had 1-in. flanged edges. The flange of the lower side had a $1 / 2$-in. out ward extension parallel to the face of the panel. Two clips made of 1-in. strap iron were welded to

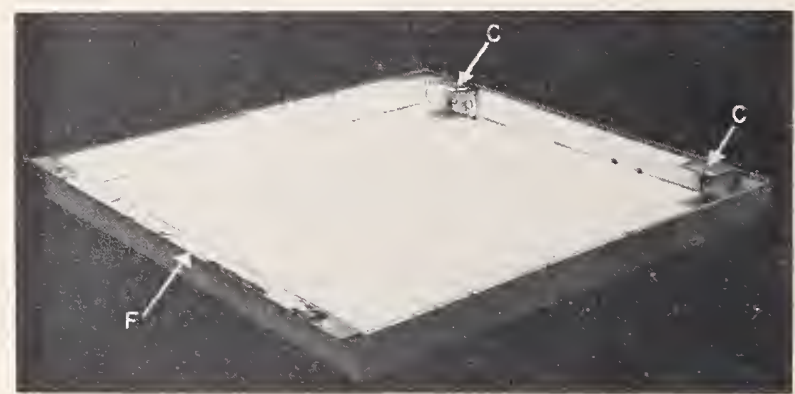

FIguRE 1. Reverse side of an exposure panel.

C, Attaehment clips; F, lower flange estension used for fastening panels to raeks. the top flange so as to extend downward (see fig: 1). The clips and the lower flange extension fitted into 18-gage galvanized-iron channels, which in turn were firmly attached to the supporting racks. The crevices between the specimens were not calked but were left open tc facilitate removal of the panels during periods of inspection.

The supporting racks were constructed of $3 / 16$-in. angle iron and, after priming, were painted periodically with aluminum paint. Each rack was constructed to support 28 of the $1-\mathrm{ft}$-squart panels. Seven racks were required for each location. At those locations where the panels were exposed on flat roofs (see table 1), the racks were anchored with weights, and at the grounc locations the racks were anchored to piers o concrete blocks. Figure 2 shows the installation at Washington, D. C.

TABLE 1. Exposure-test locations

\begin{tabular}{|c|c|c|}
\hline City & Exposure site & $\begin{array}{l}\text { Exposure conditions } \\
\text { represented }\end{array}$ \\
\hline Washington, D.C. & $\begin{array}{l}\text { Roof, Industrial Bldg. } \\
\text { National Bureau of }\end{array}$ & $\begin{array}{l}\text { Temperate, residen- } \\
\text { tial. }\end{array}$ \\
\hline St. Louis, Mo - & $\begin{array}{l}\text { Roof, Union Electric } \\
\text { Co. Warehouse. }\end{array}$ & $\begin{array}{l}\text { Temperate, indus- } \\
\text { trial. }\end{array}$ \\
\hline Lakeland, Fla & $\begin{array}{l}\text { Ground Municipal Air- } \\
\text { port }\end{array}$ & $\begin{array}{l}\text { Semitropical, resi- } \\
\text { dential. }\end{array}$ \\
\hline Atlantie City, N. $J$ & $\begin{array}{l}\text { Ground, U. S. Coast } \\
\text { Guard station. }\end{array}$ & $\begin{array}{l}\text { Temperate, "salt } \\
\text { air." }\end{array}$ \\
\hline
\end{tabular}

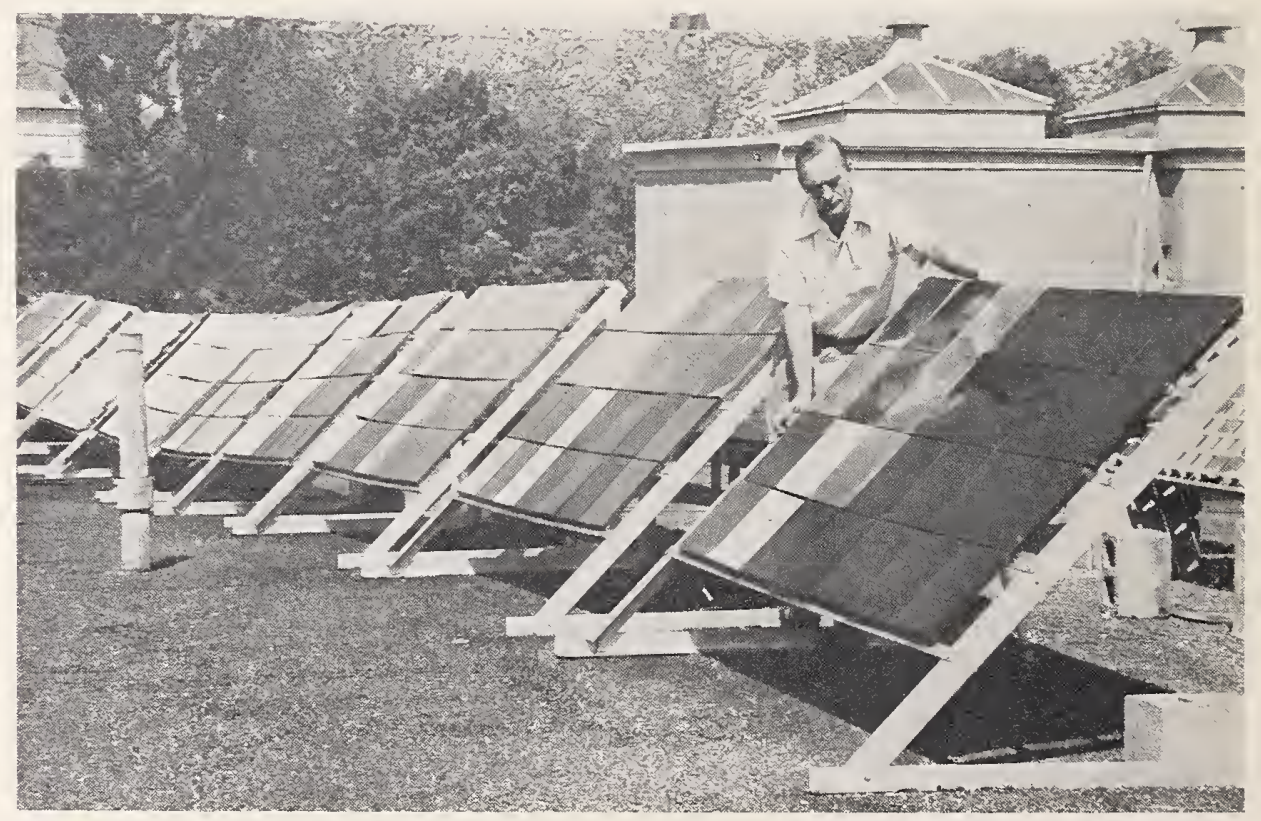

Figure 2. Exposure-test installation on the roof of the Industrial Building at the National Bureau of Standards. 
Table 1 lists the locations and general conditions of exposure. Table 2 gives weather data or the actual period of exposure. At all four ocations the racks faced south, the panels being xposed at $45^{\circ}$ to the horizontal.

TABLE 2. General weather data for the 15-yr exposure period (from $L^{*}$. S. Weather Bureau Records)

\begin{tabular}{|c|c|c|c|c|}
\hline City & Exposure Period & $\begin{array}{l}\text { Annual } \\
\text { rain. } \\
\text { fall a }\end{array}$ & $\begin{array}{l}\text { Annual } \\
\text { sun. } \\
\text { shine a }\end{array}$ & $\begin{array}{l}\text { Arer- } \\
\text { age } \\
\text { temper- } \\
\text { ature } 8\end{array}$ \\
\hline Wasbington, D. C... & Dec. 1939 through & $\begin{array}{l}\text { in. } \\
\text { 42. } 0\end{array}$ & $\begin{array}{c}h r \\
2,584\end{array}$ & $\begin{array}{l}\circ F \\
57.6\end{array}$ \\
\hline St. Louis, $\mathrm{M}_{0} \ldots$ & Apr. 1940 through & 36.3 & 2.718 & 5 S. 2 \\
\hline Lakeland, Fla_ & July 1940 through & 47.8 & b 2878 & 72.8 \\
\hline Atlantic City. . . J. & $\begin{array}{l}\text { Aug. } 19.10 \text { through } \\
\text { - }\end{array}$ & 40.0 & 2,675 & 55.6 \\
\hline
\end{tabular}

3 A rerage computed for actual period of exposure.

b Taken from Tampa, Fla., records. A rerage annual sunshine for Lake. and not arailable.

\section{Results}

\subsection{Ease of Cleaning}

At the beginning of the inrestigation it was planned to clean the panels prior to making gloss and color measurements by washing the test surface with a 1-percent-by-weight solution of trisodium phosphate. This cleaning procedure was satisfactory for the first year's inspection [3], and at all locations except St. Louis for the inspection after 7 ir [4]. However, it was not practicable to clean the panels between inspections, and, as a result, both the Lakeland and Atlantic City panels, in addition to those from st. Louis, had accumulated surface films after the 15 -rr exposure that could not be removed by washing with the trisodium phosphate solution. The film on some of the Lakeland panels was chalky in nature, whereas rust stains were present on many of the Atlantic City panels. The film on the St. Louis panels consisted of a fairly heavy deposit of fly ash and soot bonded with a tar-like substance. Gloss- and color-difference measurements made on such surfaces would be meaningless; therefore, all panels, including those at Washington, were cleaned prior to the $15-\mathrm{rT}$ measurements by scrubbing with a commercial scouring powder. It was believed that this cleaning procedure was justified inasmuch as it followed closely the practice of commercial signcleaning services. The procedure followed in the cleaning was to continue the scouring until further treatment caused no appreciable change in the appearance of the enamel surface. In most cases, it was found that the surfaces reached substantially constant values of gloss and color by the time the cleaning was adjudger satisfarctory by visual examination.

The case of cleaning varied witli the acid resistance of the enamel, the surfaces of high arid resistance being easier to clean than those of $\mathrm{por}^{\circ}$ acid resistance. The semimat or satin-texturerl enamels showed about the same cleaning behavior as the glossy surfaces after weathering. On the other hand, none of the full-mat enamels could be cleaned satisfactorily even by a vigorous and prolongerl scouring treatment.

\subsection{Corrosion Protection}

All of the panels were inspecter for evidence of corrosion. Where the initial coverage was complete on all parts of the panel no corrosion was noted, irrespective of the type of enamel applierl. However, on many panels the under side was protected with only a single groundcoat application, and good coverage of the metal was not alwats achieved. Corrosion started at these areas of poor coverage, and spalling of the enamel on the face side occurred after the corrosion had progressed only part way through the thickness of steel

Hydrogen originating from the action of condensed moisture on the unprotected steel is believed responsible for the spalling. Norton [5] has shown by a tracer technique that the hydrogen generated from such a reaction will permeate the steel structure at room temperature, and numerous investigators, including Zappfe and Sims [6], have demonstrated that whenever hydrogen diffuses through steel, sufficient pressure can be gencrated to rupture the enamel on the opposite face. Thus. it appears entirely reasonable that the observed spalling behavior could be caused by hydrogen diffusion.

The surface spalls, which resembled large fishscales, were noted on only a few of the panels at Atlantic City at the $7-\mathrm{rr}$ inspection. Howerer. after $15-y^{2}$, the majority of the panels at that location showed one or more of these surface spalls.

Figure 3 is a comparison of panels having good coverage on the under side (tro or more cnamel applications) with similar panels that hal poor coverage (a single ground coat with local breaki in the coating). All four of these panels were from the Atlantic City site, where col'tosion on the unprotected metal was especially serere becinse of the "salt-air" conditions. Fortmintely. the conter area of the panels was free of spalls in almost all cases, and therefore they did not interfore with the gloss and color measurements.

Surface spalls from poor corcrige on the umeter side were noted also on a few of the pamels at -1 Louis and Lakchand. The following tabulation

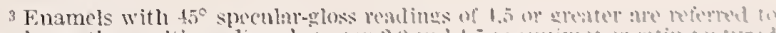

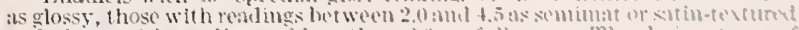

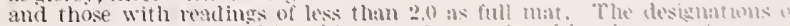

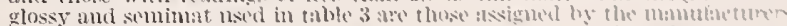

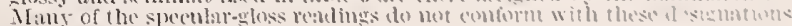


gives the prevalence of surface spalls at each of the four locations:

Exposure site
Percentage of penels showing one or more surface spalls
Atlantic City

St. Loulis

Lakeland

IT ashington

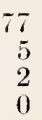

Noticeable edge corrosion ${ }^{4}$ was observed only on the panels exposed to the salt-air conditions at Atlantic City. In no case, however, was this edge corrosion considered to be serious. Numerous observations made during the 15 -vr inspection indicated that whenever corrosion started at an edge or at any area of poor coverage, there was very little spreading of the corrosion under the adjacent enamel.

Some of the top attachment clips (see fig. 1) showed serious corrosion in the salt air at Atlantic City. These clips had been spotwelded to the panels prior to enameling and, in some cases, the enamel coverage was poor where the clip joined the panel. Corrosion occurred at these points, the clips came loose from the panels, and, in a few instances, the affected panels were blown away

\pm Good coverage is difficult to achieve on the edge of a thin sheet and, henee, many of the panel edges were not properly covered with enamel.

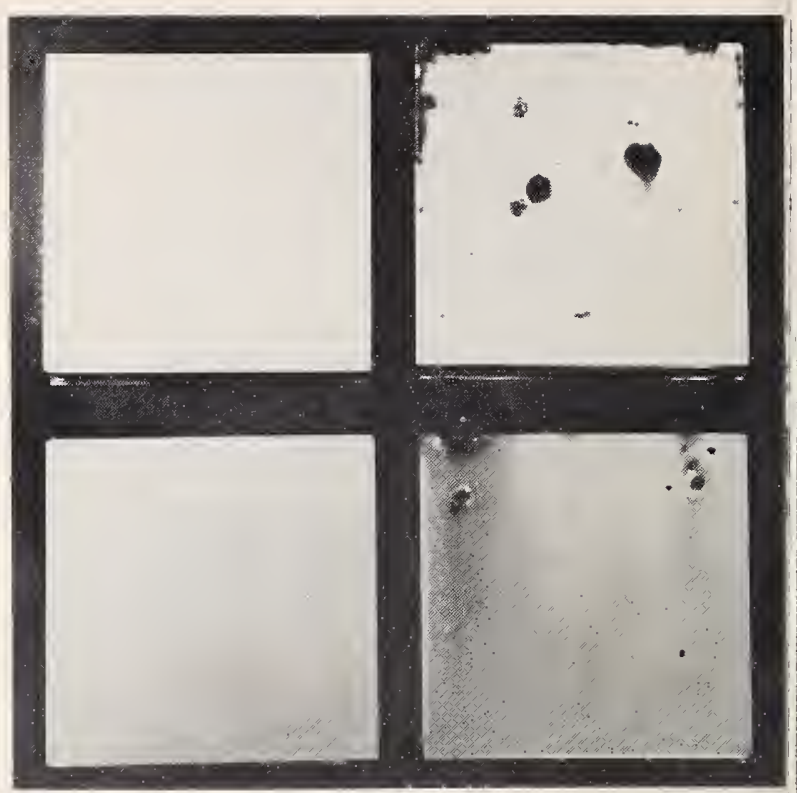

FIgURE 3. Four panels after 15 years of exposure at Allantic City.

Speeinens on left had good enamel coveragc, whereas the two on the right show holes in the panel caused by rusting through from areas of inenmplete eoverage on the baek side.

from the rack during the periods of high wind velocity. As a result, some of the data for Atlantic City are missing from table 3 .

TABLE 3. Percentage of initial specular gloss retained, color-difference values, weather-resistance ratings, and acid resistance of enamels of 14 types after 15 years of exposure at 4 sites

\begin{tabular}{|c|c|c|c|c|c|c|c|c|c|c|c|c|c|}
\hline \multirow[b]{2}{*}{ Specimen identifieation ${ }^{a}$} & \multirow{2}{*}{$\begin{array}{l}\text { Fabriea- } \\
\text { tor of } \\
\text { speei- } \\
\text { mens }\end{array}$} & \multirow{2}{*}{$\begin{array}{l}\text { Frit } \\
\text { sup- } \\
\text { plier }\end{array}$} & \multirow{2}{*}{$\begin{array}{c}\text { A verage } \\
\text { initial } \\
\text { specular } \\
\text { gloss, b } \\
G S\end{array}$} & \multicolumn{8}{|c|}{ Initial gloss retained $\left(G_{R}\right)$ and change in color $(\Delta E)$ at $-{ }^{e}$} & \multirow{2}{*}{$\begin{array}{l}\text { Acid re- } \\
\text { sistance } \\
(\mathrm{PEI} \\
\text { test) }\end{array}$} & \multirow{2}{*}{$\begin{array}{l}\text { Weather } \\
\text { resist- } \\
\text { anee } \\
\text { 1atinge }\end{array}$} \\
\hline & & & & \multicolumn{2}{|c|}{ Washington } & \multicolumn{2}{|c|}{ Lakeland } & \multicolumn{2}{|c|}{ St. Louis } & \multicolumn{2}{|c|}{ Atlantic City } & & \\
\hline
\end{tabular}

WHITE, GLOSSY, ACID-RESISTANT ENAMEL

A-1 to 8

A-11 to 18

A-21 to 28

$A-21$ to 28
$A-31$ to 38

A-41 to 48

A-51 to 58

A-61 to 68

A -71 to 78

A verage

$\%$
5.70
5.74
6.04
6.01
5.85
5.81
6.20
6.01

WHITE, GLOSSY, NONACID-RESISTANT ENAMEL

B-1 to 8

B-21 to 28

B-41 to 48

B-61 to 68

Average .

\begin{tabular}{|ll}
$\mathrm{a}$ & 1 \\
$\mathrm{~b}$ & 1 \\
$\mathrm{a}$ & 2 \\
$\mathrm{~b}$ & 2 \\
$\mathrm{a}$ & 3 \\
$\mathrm{~b}$ & 3 \\
$\mathrm{a}$ & 4 \\
$\mathrm{~b}$ & 4 \\
\hline
\end{tabular}

\begin{tabular}{l}
$\%$ \\
83.1 \\
86.9 \\
84.2 \\
76.6 \\
85.0 \\
85.4 \\
83.3 \\
73.4 \\
\hline
\end{tabular}

\begin{tabular}{rr|}
0.7 \\
1.0 \\
0.6 \\
.5 \\
3.0 \\
1.2 \\
1.1 \\
1.7 \\
\hline
\end{tabular}

1. 2

\begin{tabular}{|c|c|c|}
\hline $\begin{array}{l}\% \\
689\end{array}$ & 0.8 & $\begin{array}{c}\% \\
766\end{array}$ \\
\hline 88.7 & 10 & 755 \\
\hline 68.4 & 0.3 & 77.5 \\
\hline 66.6 & 3 & 85.8 \\
\hline 62.2 & 29 & 827 \\
\hline 48.8 & 24 & 85.6 \\
\hline 660 & 3.5 & 73.6 \\
\hline 863 & 1.7 & 799 \\
\hline 69 & 1. 6 & 79.6 \\
\hline
\end{tabular}

\begin{tabular}{|c|c|}
\hline$\%$ & \\
76.6 & 0.8 \\
75.5 & 9 \\
77.5 & 1.4 \\
85.8 & 0.6 \\
82.7 & 2.1 \\
85.6 & 1.0 \\
73.6 & 1.6 \\
79.9 & 2.3 \\
\hline 79.6 & 1.3 \\
\hline
\end{tabular}

\begin{tabular}{|c|}
$\%$ \\
66.7 \\
89.6 \\
88.3 \\
84.4 \\
81.7 \\
46.8 \\
72.1 \\
77.8 \\
\hline 75.9 \\
\hline \\
\\
$(f)$ \\
19.0 \\
15.0 \\
18.7 \\
\hline 17.6
\end{tabular}

1. 1

2.2
0.9

0.9

1.6
2.2
3.6

$\begin{array}{ll}3.6 & \text { AA } \\ 3.1 & \text { A A }\end{array}$

1. 9

A A

AA

AA

A A

A

-.....
E

E

E

F

G

\begin{tabular}{|c|c|c|c|c|c|c|c|c|c|c|}
\hline $\begin{array}{l}5.26 \\
5.41 \\
5.16 \\
5.32\end{array}$ & $\begin{array}{l}18.0 \\
15.0 \\
15.0 \\
16.4\end{array}$ & $\begin{array}{l}2.9 \\
4.8 \\
2.7 \\
3.1\end{array}$ & $\begin{array}{l}62.8 \\
32.6 \\
38.5 \\
56.0\end{array}$ & $\begin{array}{l}1.1 \\
4.6 \\
1.9 \\
0.5\end{array}$ & $\begin{array}{l}46.1 \\
41.3 \\
38.6 \\
35.5\end{array}$ & $\begin{array}{l}8.6 \\
6.3 \\
5.9 \\
6.9\end{array}$ & $\begin{array}{c}\text { (f) } \\
19.0 \\
15.0 \\
18.7\end{array}$ & 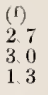 & $\begin{array}{l}\mathrm{C} \\
\mathrm{C} \\
\mathrm{I} \\
\mathrm{C}\end{array}$ & $\begin{array}{l}\mathrm{P} \\
\mathrm{P} \\
\mathrm{P} \\
\mathrm{P}\end{array}$ \\
\hline$\ldots$ & 16.1 & 3.4 & 47.5 & 2.0 & 40.4 & 6.9 & 17.6 & 2.3 & 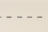 & -. \\
\hline
\end{tabular}

WHITE, SEMIMAT, ACID-RESISTANT ENAMEL

C-11 to 18 C-31 to 38 C-51 to 58

C.71 to 78

Average

\begin{tabular}{l|l|l|l|l|l|l|l|l|l|l|l}
4.06 & 30.3 & 1.5 & 54.4 & 1.1 & 82.6 & 5.2 & 43.5 & 1.6 & $\mathrm{C}$ & $\mathrm{P}$ \\
5.24 & 42.1 & 2.3 & 40.8 & 1.7 & 92.3 & 0.9 & 46.6 & 1.5 & $\mathrm{~A}$ & $\mathrm{~F}$ \\
5.16 & 76.7 & 2.2 & 63.9 & 1.9 & 80.7 & 3.8 & 55.6 & 2.2 & $\mathrm{~A}$ & $\mathrm{G}$ \\
$\mathbf{5 . 3 2}$ & 54.8 & 1.3 & 33.0 & 1.9 & 86.7 & 0.6 & 46.1 & 0.8 & $\mathrm{~A}$ & $\mathrm{P}$ \\
\hline & 51.0 & 1.8 & 48.0 & 1.6 & 8.5 & 2.3 & 47.9 & 1.5 & $\ldots$ & \\
\hline
\end{tabular}


TABLE 3. Percentage of initial specular gloss retained, color-difference values, weather-resistance ratings, and, acid resistance of enamels of 14 types after 15 years of exposure al 4 sites-Continued

\begin{tabular}{|c|c|c|c|c|c|c|c|c|c|c|c|c|c|}
\hline \multirow{3}{*}{ Epecimen identifications } & \multirow{3}{*}{$\begin{array}{c}\text { Fabrica- } \\
\text { tor of } \\
\text { speci- } \\
\text { mens }\end{array}$} & \multirow{3}{*}{$\begin{array}{l}\text { Frit } \\
\text { sup- } \\
\text { plier }\end{array}$} & \multirow{3}{*}{$\begin{array}{l}\text { A verage } \\
\text { initial } \\
\text { specular } \\
\text { gloss,b } \\
G S\end{array}$} & \multicolumn{8}{|c|}{ Initial gloss retained $\left(G_{f}\right)$ and change in color $(\Delta E)$ at $-c$} & \multirow{3}{*}{$\begin{array}{l}\text { Acid re- } \\
\text { sistance } \\
\text { (PEI } \\
\text { test)d }\end{array}$} & \multirow{3}{*}{$\begin{array}{l}\text { Weiather } \\
\text { re'sist- } \\
\text { ance. } \\
\text { rating }\end{array}$} \\
\hline & & & & \multicolumn{2}{|c|}{ Washington } & \multicolumn{2}{|c|}{ Lakeland } & \multicolumn{2}{|c|}{ St. Louis } & \multicolumn{2}{|c|}{ Atlantíc City } & & \\
\hline & & & & $G_{R}$ & $\Delta E$ & $r_{R}$ & $\Delta E$ & $G_{H}$ & $\Delta E$ & $G_{R}$ & $\Delta E_{i}$ & & \\
\hline
\end{tabular}

WHITE, SEMMAT, NONACID-RESISTANT ENAMEL

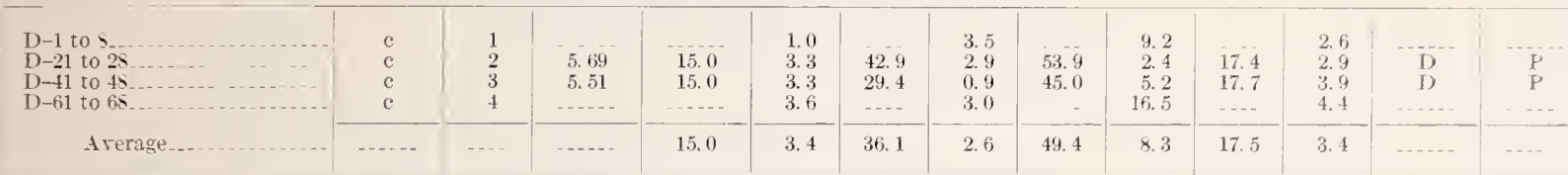

BUFF, GLOSSY, ACID-RESISTANT ENAMEL

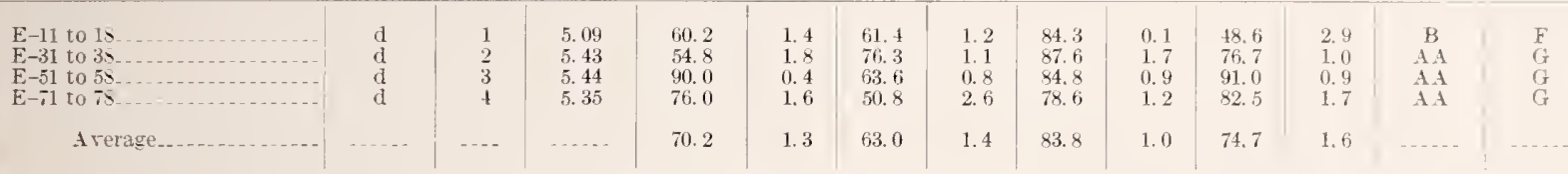

BUFF, GLOSSY, NONACID-RESISTANT ENAMEL

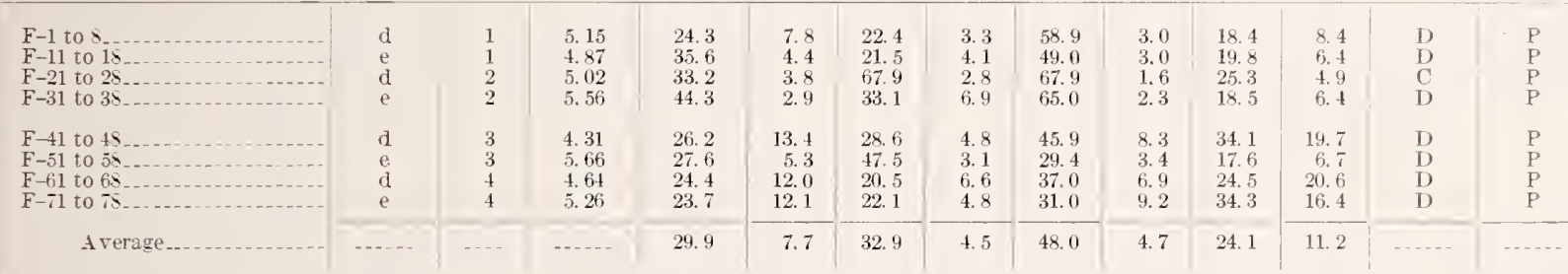

BUFF, SEMIMAT, ACID-RESISTANT ENAMEL

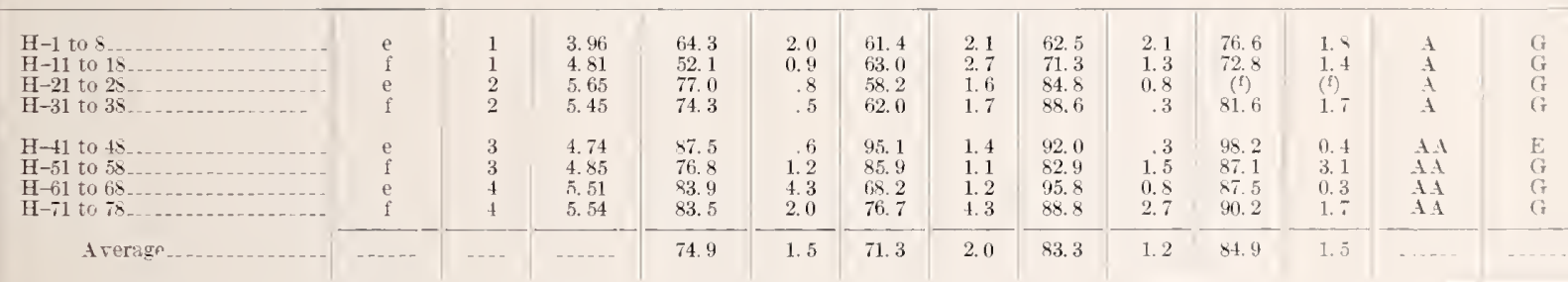

RUFF, SEMIMA, NOAACID-RESISTANT ENAMEL

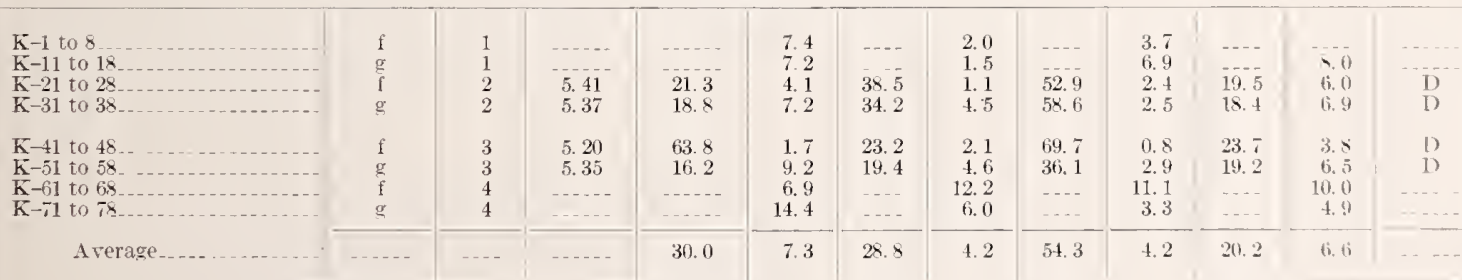

RED, GLOSSY, ACID-RESISTANT ENAMEL

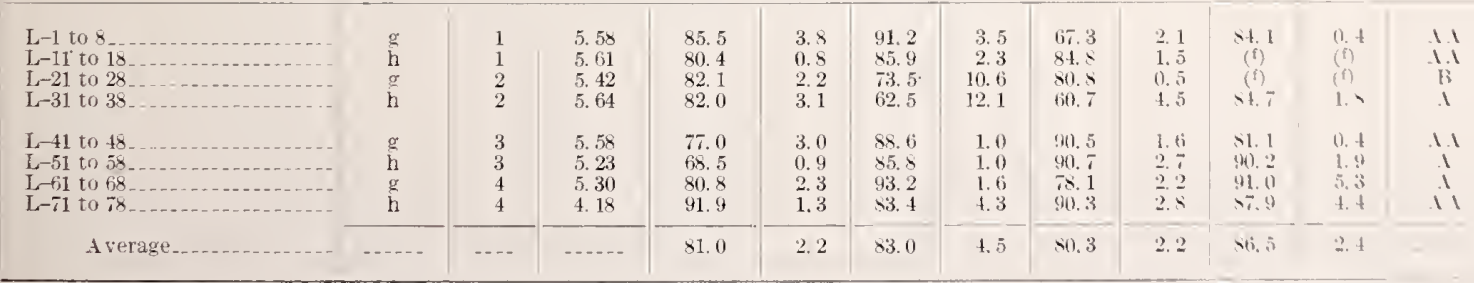


TABLE 3. Percentage of initial specular gloss retained, color-difference values, weather-resistance ratings, and acid resistance of enamels of 1 I $_{t}$ types after 15 years of exposure at 4 sites-Continued

\begin{tabular}{|c|c|c|c|c|c|c|c|c|c|c|c|c|c|}
\hline \multirow[b]{2}{*}{ Specimen identifications } & \multirow{2}{*}{$\begin{array}{c}\text { Fabrica- } \\
\text { tor of } \\
\text { speci- } \\
\text { mens }\end{array}$} & \multirow[b]{2}{*}{$\begin{array}{l}\text { Frit } \\
\text { sup- } \\
\text { plier }\end{array}$} & \multirow{2}{*}{$\begin{array}{l}\text { Arerage } \\
\text { initial } \\
\text { specular } \\
\text { gloss, b } \\
G S\end{array}$} & \multicolumn{8}{|c|}{ Initial gloss retained $\left(G_{R}\right)$ and change in color (\lrcorner $\left.E\right)$ at $-{ }^{c}$} & \multirow{2}{*}{$\begin{array}{l}\text { Acid re- } \\
\text { sistance } \\
\text { (PEI } \\
\text { test)d }\end{array}$} & \multirow{2}{*}{$\begin{array}{l}\text { Weather } \\
\text { resist- } \\
\text { ance } \\
\text { ratinge }\end{array}$} \\
\hline & & & & \multicolumn{2}{|c|}{ Washington } & \multicolumn{2}{|c|}{ Lakeland } & \multicolumn{2}{|c|}{ St. Louis } & \multicolumn{2}{|c|}{ Atlantic City } & & \\
\hline
\end{tabular}

RED, CLOSSY, NONACID-RESISTANT ENAMEL

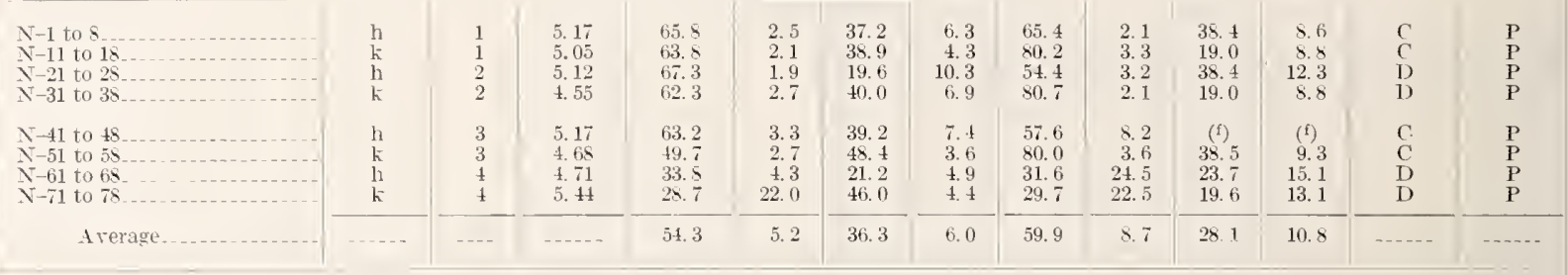

RED, SEMIMAT, ACID-RESISTANT EXAMEL

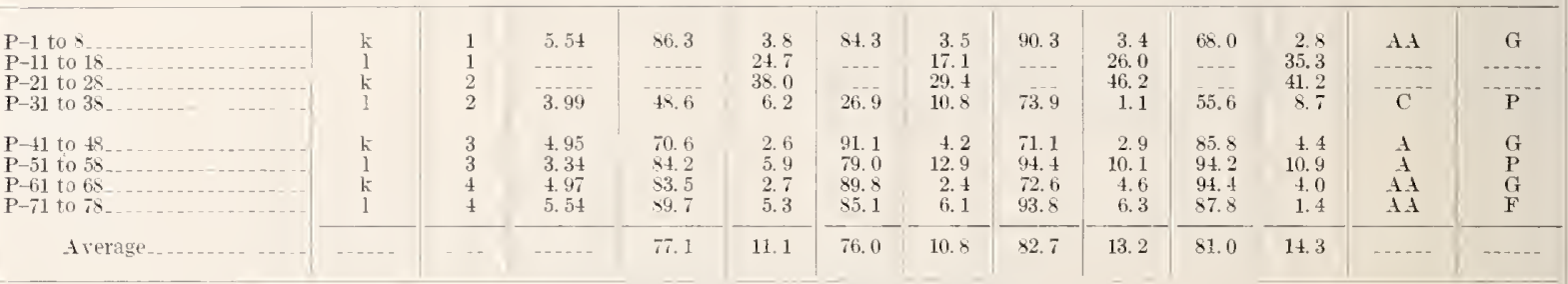

RED, SEMIMAT, NONACID-RESISTANT ENAMEL

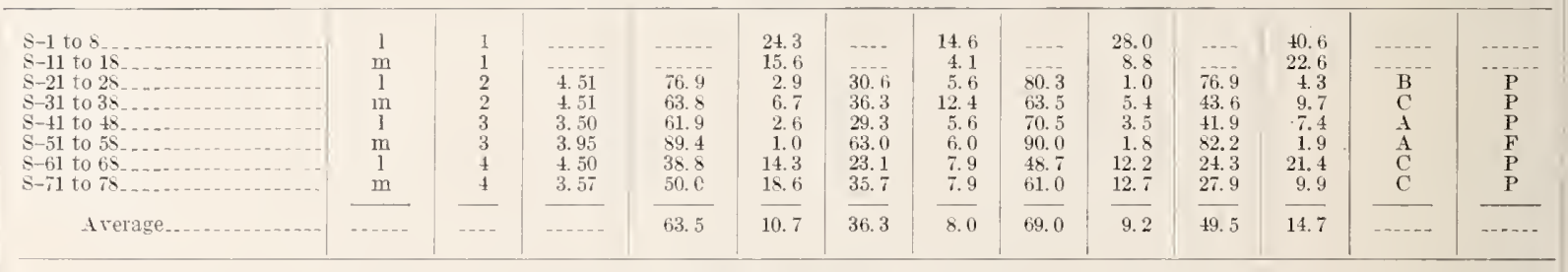

BLACK, C:LOSST, ACID-RESISTANT ENAMEL

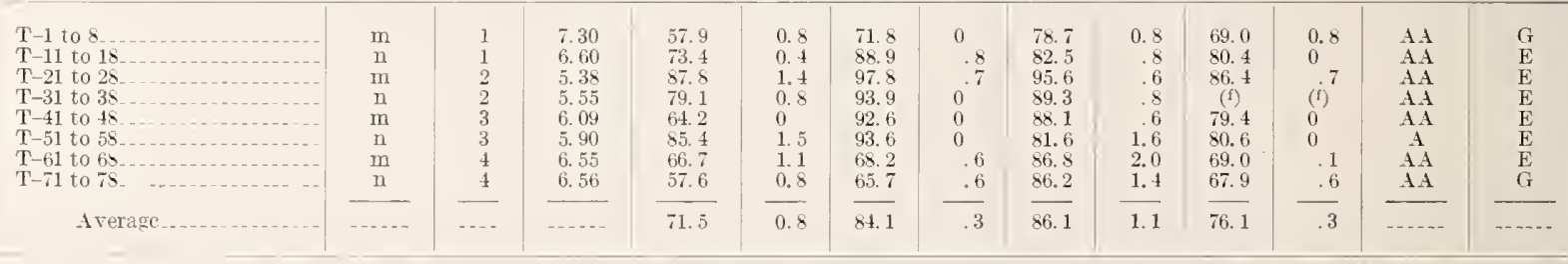

BLACK, GIOSSY, NONACID-RESISTANT ENAMEL

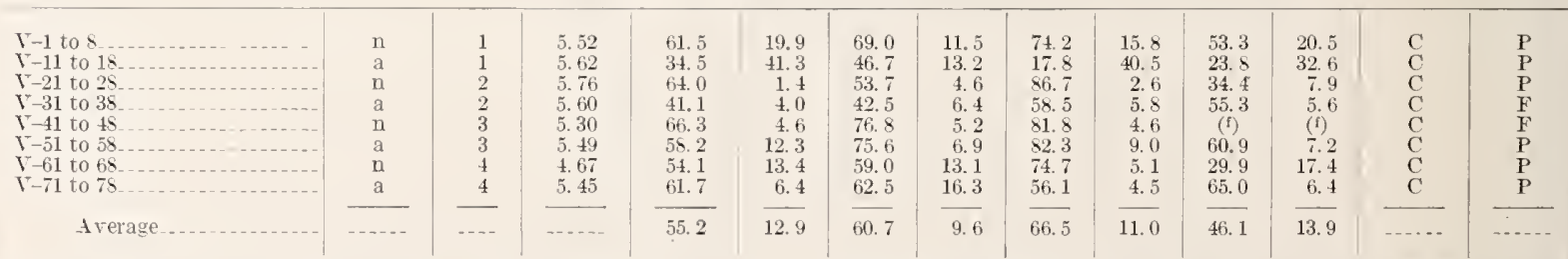

s Groups of s panels exposed, 2 at each location. A ninth panel was kept

b Figures reported are for percentage of light incident at $45^{\circ}$ that was specularly reflected. Enamels with $45^{\circ}$ specular-gloss readings of 4.5 or greater are referred to as glossy, those with readings hetween 2.0 and 4.5 as semimat or satin-textured, and those with rcadings of less than 2.0 as full mat. The designations of glossy and semimat used in the headings are those assigned hy the manufacturers. Many of the initial specular-gloss readings do not conform with these designations. The full-mat enamels haring initial gloss too low for measurement are represented hy hlank spaces in columns.

- Percentage of gloss retaincd, $G \mathrm{R}$, was computed from $45^{\circ}$ specular-gloss readings. Color change, $\Delta E$, is in NBS units as computed from color- difference measurements. Values in both cases are arerage of 2 panels with 2 readings on each panel.

d Test made on storage panel in accordance with Test for Acid Resistance of Porcclain Enamels, part I, Flatware. Issued by the Procelain Enamel Institute, 114519 th St., N. W., Washington $6, \mathrm{D}$. C. In this test the degree of attack is evaluated after treatment with citric acid. Class $A$ i shows no visihle effect from the treatment and is the most resistant, with class $A$, class $\mathrm{B}$, class $\mathrm{C}$, and class $\mathrm{D}$ following in that order. Enamels falling in the latter two classes are not considered acid resistant.

e E, cxcellent; G, good; F, fair; and P, poor. Sec text for procedure used in assigning ratings.

¿ Panels lost to study hecause of corrosion of attachment lugs. 


\subsection{Gloss Measurements}

specular-gloss measurements were made on cach panel with the Hunter Multipurpose Reflectometer $[\bar{\tau}]$ a djusted for a $45^{\circ}$ angle of incidence. The gloss scale of the instrument was calibrated against liquid films [8]. Measurements were made at two fixed locations at the center of each panel and compared with similar measurements made at the start of the inrestigation. The data were expressed as the percentage of initial specular gloss retained.

Table 3 includes the gloss data for each enamel at the four exposure sites. ${ }^{5}$ Comparison with the results of the $7-\mathrm{r}$ inspection [4] shows that the percentage of gloss retained in many cases was higher after $15 \mathrm{vr}$ than it was after $7 \mathrm{yr}$. This effect is due to the difference in cleaning treatment, the panels at 7 ir having been washed with trisodium phosphate solution, whereas the scouring treatment was required to clean the specimens for the 15 -rr measurements.

Except for a fer isolated cases, the percentage of gloss retained was considerably higher for enamels of high acid resistance than for the nonacid-resistant trpes. The enamel showing the least change in gloss for all four locations after 15 1T was an acid-resistant black ( $\mathrm{T}-21$ to 28 ), which retained an arerage of 91.9 percent of its initial gloss. Among the poorest was a nonacidresistant composition ( $\mathrm{K}-51$ to 58 ), which had an arerage percentage of gloss retained for the four locations of only 22.7.

In general it was noted that the specular gloss changed at a faster rate in the earlier stages of exposure than later. Figure 4 illustrates this effect for fire panels at Washingt on, D. C., whose surfaces had been washed with trisodium phosphate solution. These same panels, along with all others from Washington, were later cleaned br scouring so as to conform to the cleaning procedure used at the other thrce locations. The effect of the scouring treatment in raising the percentage of gloss retained br the fire panels is shown by the following tabulation:

\begin{tabular}{|c|c|c|c|}
\hline \multirow{2}{*}{ Panel } & \multirow{2}{*}{$\begin{array}{c}\text { Acid resist- } \\
\text { ance (PEI } \\
\text { test) }\end{array}$} & \multicolumn{2}{|c|}{$\begin{array}{l}\text { Percentage of gloss } \\
\text { retained }\end{array}$} \\
\hline & & $\begin{array}{c}\text { Washed with } \\
\mathrm{Na}_{3} \mathrm{PO}_{4}\end{array}$ & $\begin{array}{l}\text { Cleaned with } \\
\text { scouring } \\
\text { powder }\end{array}$ \\
\hline $\begin{array}{l}\mathrm{E}-1 \\
\mathrm{P}-41 \\
\mathrm{E}-12 \\
\mathrm{C}-11 \\
\mathrm{~B}-41\end{array}$ & $\begin{array}{l}A . A \\
A \\
B \\
C \\
D\end{array}$ & $\begin{array}{l}64.3 \\
56.3 \\
48.0 \\
27.2 \\
16.1\end{array}$ & $\begin{array}{l}76.0 \\
71.7 \\
53.1 \\
28.6 \\
15.0\end{array}$ \\
\hline
\end{tabular}

3 The initial gloss values, $G$, are expressed as the pereentage of incident light that is speculariy reflected. This conforms to the prartice used in the earlier papers. Recent practice in the industry, howerer, is to expless the ralues in "gloss units," defined as $10 \times G_{6}$.

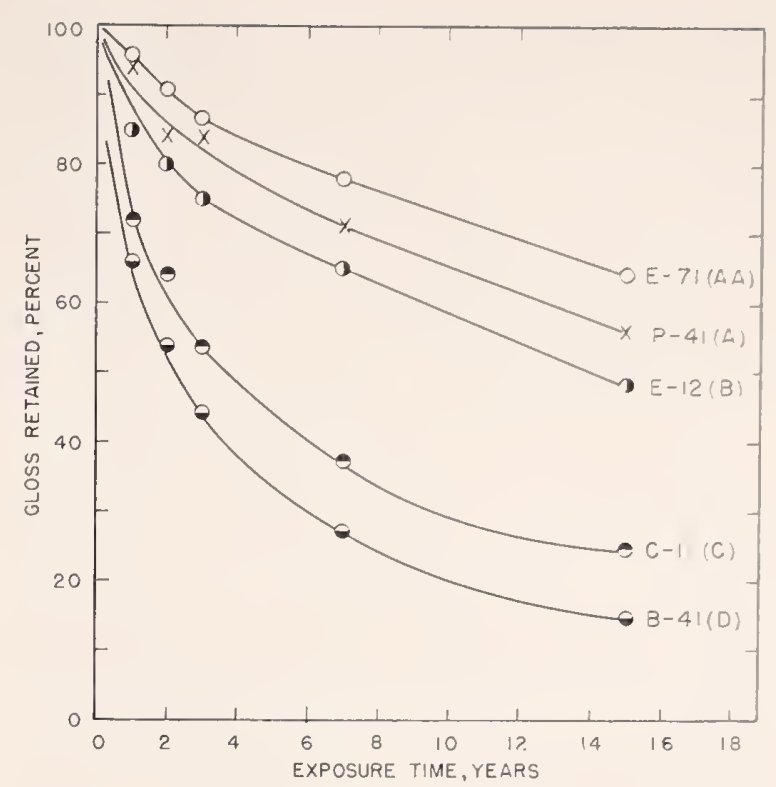

FIgure 4. Selected data showing change in gloss with exposure time for five panels at the Washington, $D$. C., site.

Letters following panel numbers indicate acid-resistance ratings by citric acid spot test.

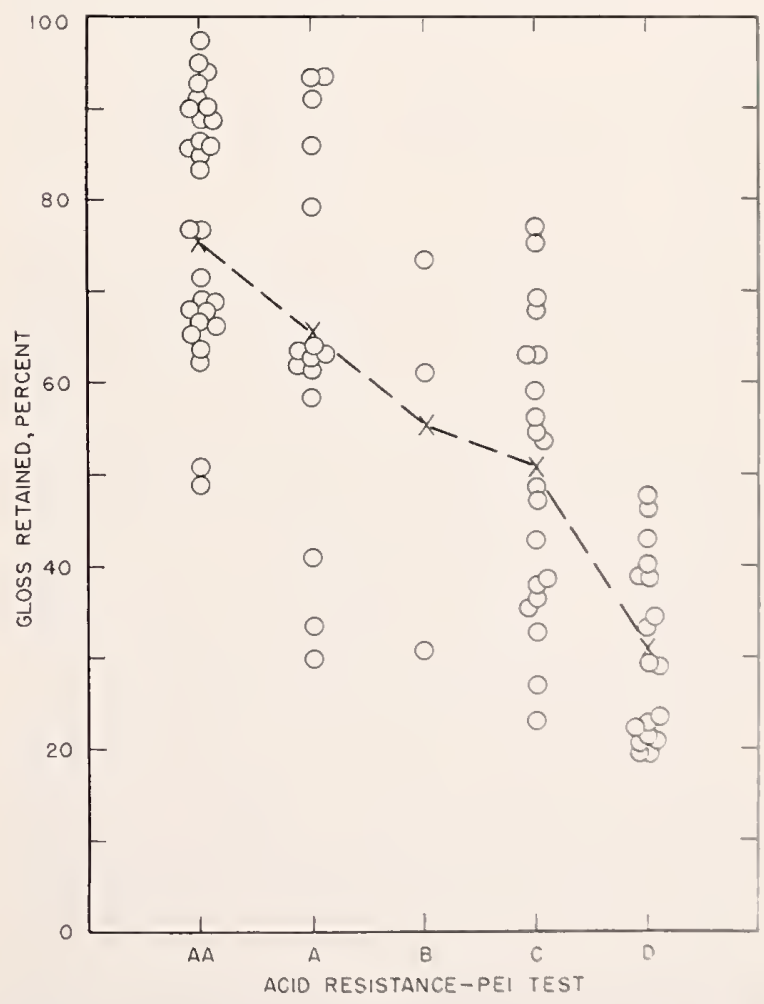

Firtere 5. Percentage of glose retained for enemes of pir classes of acid resistame alter cxposure for 1.7 leas at Lakeland, Fla.

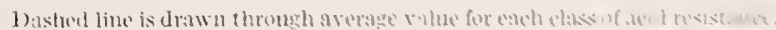


The curves plotted in figure 4 represent selected data, in that these particular five panels were the ones that best illustrated the usual weathering behavior of enamels having different degrees of acid resistance when measured by the citric acid spot test of the Porcelain Enamel Institute ${ }^{6}$ Actually, table 3 shows appreciable differences in the percentage of gloss retained for enamels of the same acid resistance. This high scatter for the Lakeland panels is illustrated in figure 5 .

\subsection{Color-Difference Measurements}

The color changes that occurred during the 15-rr exposure period were measured with a Huinter Color-Difference Meter [9]. In each case, the exposed panel was compared with the storage panel, and the difference between the rwo expressed in INBS units [10]. Diffuse reflectance measurements were made at the begimning of the investigation, and these indicated excellent color match between the storage panels and the ones selected for exposure. One NBS unit is about five times the smallest difference perceptible to the eye under the best experimental conditions [11]. It is the opinion of the authors that five NBS units might be considered objectionable by a user, especially if two panels showing such a color difference were placed side by sicke in a structure. A change of 10 units due to weathering would probably be objectionable in most installations where retention of a specified color is important, for example in signs and structures where the color has been specially selected as an identifring characteristic.

Table 3 shows that color changes were minor for the white enamels, except for the St. Louis panels of poor acid resistance. These are the same enamels that became etched during weathering. Dirt and grime in the atmosphere at the st. Louis site entered the pores created by the etching action, and these dirt particles could not be removed completely by the cleaning treatment. The prescnee of the dirt particles retained after cleaning made the panels appear off-white to the eye and darker to the color-difference meter. At the other sites, there was less pollution of the atmosphere, and dirt retention after cleaning of the nonacid-resistant enamels had a much smaller effect on the color-difference measurements.

The colored enamels of poor weather resistance became lighter and weaker in color with exposure, which gave them a faded appearance. The greatest color change was observed for the full-mat enamels, $\mathrm{P}-11$ to $1 \mathrm{~S}, \mathrm{P}-21$ to $28, \mathrm{~S}-1$ to $\mathrm{S}$, and $S-11$ to 18 in table 3 ; in addition, these were the compositions that were the most difficult to clean. 6 Test for Acid Resistance of Porcelain Enamels, part 1, Flatware. Issued
by the Porcelain Enamel Institute, 114519 th $\mathrm{St}$, N. W. Washington 6 , D. C
In the commercial test, which separates enamels according to classes, a small
pool of 10 -percent citric acid is placed on the specimen for $15 \mathrm{~min}$ at $80^{\circ} \mathrm{F}$.
The degree of attack is then eraluated risually by observing such character-
istics as staining, blurring of image, and ease of remoral of a pencil mark.
Class A shows no risible effect from the treatment and is most resistant,
with Class A, Class B, Class C, and Class D following in that order.
Enamels falling in the latter two classes are not considered acid resistant.

\subsection{Microstructure of Surfaces}

The surfaces of the enamels that were examined with the metallographic microscope at the $7-\mathrm{yr}^{\circ}$ inspection were reexamined after 15 yr of exposure. In general, the appearances of the surfaces were unchanged. The enamels showing little or no change in surface microstructure at $7 \mathrm{yr}$ still showed little or no change at $15 \mathrm{yr}$. The photomicrographs shown in the earlier report [4] of enamels of poor acid resistance are representative also of the $15-\mathrm{yr}$ appearance. A gel-type layer was present on enamels of this type, and the thickness of the layer was found to increase with exposure time, but this increase occurred without much change in surface appearance. 'The thickness of the layer varied with enamel composition. On a black nonacid-resistant enamel, represented by panels $T-11$ to $V-18$, the thickness had increased from an average of $0.001 \mathrm{in}$. at $7 \mathrm{rr}$ to a thickness of about 0.0025 in. at 15 IT. The film still maintained a glossy surface appearance, but was soft enough to be scraped away with a knife blade. Table 3 shows the average color change of this enamel at the four locations to be 31.9 NBS units.

Similar gel-like films of measurable thickness had formed on some of the other enamels of poor acid resistance after the 15 -yr exposure period. For example, panel P-27 (Atlantic City) showed a film thickness of $0.0005 \mathrm{in.}, \mathrm{V}-63$ (Lakeland) a thickness of $0.0004 \mathrm{in}$., and $\mathrm{V}-67$ (Atlantic City) a thickness of 0.001 in.

It should be pointed out that only those enamels of rery poor weather resistance showed layers of this type. The acid-resistant compositions may have had very thin films of a gel-like nature present on their surfaces, but, if so, the films were too thin to have any marked effect on gloss os color.

\section{Effect of Variation in Weather Con- ditions at Four Exposure Sites}

Tables 4 and 5 are summaries of the data on gloss and color difference, respectively, at the four exposure sites. For convenience, the enamels have been grouped according to their acid resistance by the Porcelain Enamel Institute Spot Test for the Acid Resistance of Flatware. In the table giving the gloss summaries (table 4) the grouping is made without considering color. The initial color, however, had a definite effect on the magnitude of the color difference after exposure. Therefore the enamels in table 5 are grouped according to both color and acid resistance.

Standard deviations are listed in both tables. In practically all cases these values are high, indicating poor agreement among panels in any one group. Nevertheless a trend appears to be

\footnotetext{
The scouring treatment used for cleaning remored the thimer gel-likc layers, but on panels having layers 0.001 in. or heavier, some of the film remained even after prolonged scouring.
} 
TABLE 4. Acerage percentages of initial specuiar gioss retained for enamels of various classes of arid resistance after 15 yr of weathering at 4 exposure sites

\begin{tabular}{|c|c|c|c|c|c|c|c|c|c|c|c|}
\hline \multirow{3}{*}{$\begin{array}{c}\text { Number of ensmels } \\
\text { averaged a }\end{array}$} & \multirow{3}{*}{$\begin{array}{l}\text { Acid-re- } \\
\text { sistance } \\
\text { class b }\end{array}$} & \multicolumn{10}{|c|}{ Percentage of initial specular gloss retained r } \\
\hline & & \multicolumn{2}{|c|}{ Washington } & \multicolumn{2}{|c|}{ Lakeland } & \multicolumn{2}{|c|}{ St. Louis } & \multicolumn{2}{|c|}{ Atlantic rity } & \multicolumn{2}{|c|}{ All sites } \\
\hline & & Arg & $S D$ & Arg & SD & Avg & ST) & $A v g$ & si) & Ave & $\Delta(\rangle$ \\
\hline $\begin{array}{l}29 \\
15 \\
3 \ldots \\
21 \\
15\end{array}$ & $\begin{array}{c}A A \\
A \\
B \\
C \\
D\end{array}$ & $\begin{array}{l}79.0 \\
71.1 \\
73.1 \\
47.5 \\
31.1\end{array}$ & $\begin{array}{r}9.9 \\
13.3 \\
9.3 \\
16.9 \\
12.0\end{array}$ & $\begin{array}{l}7.7 .7 \\
65.3 \\
55.2 \\
50.3 \\
30.5\end{array}$ & $\begin{array}{r}13.3 \\
19.8 \\
18.1 \\
15.5 \\
9.5\end{array}$ & $\begin{array}{l}84.5 \\
80.3 \\
81.8 \\
63.6 \\
48.2\end{array}$ & $\begin{array}{r}7.2 \\
10.4 \\
1.8 \\
17.6 \\
\times .9\end{array}$ & $\begin{array}{l}80.6 \\
73.6 \\
43.1 \\
37.6 \\
22.6\end{array}$ & $\begin{array}{r}10.7 \\
12.4 \\
5.5 \\
14.9 \\
6.4\end{array}$ & $\begin{array}{r}80.4 \\
72.8 \\
63.3 \\
49.7 \\
33.1\end{array}$ & $\begin{array}{l}\text { 10. } 6 \\
14.4 \\
10.6 \\
16.3 \\
11.1\end{array}$ \\
\hline
\end{tabular}

Each enamel represented br two panels at each location.

From spot tests made on 12- by 12-in. storage panels, using the standard test of the Porcelain Enamel Institute

Measurements made on panel surfaces cleaned with a commercial scouring powder: SD denotes the standard deviation of the individual rearlins the areriage.

TABLE 5. Average color differences between exposed panels and storage panels for enamels of two classes of acid rasistaret after 15 yr of weathering at 4 exposure sites

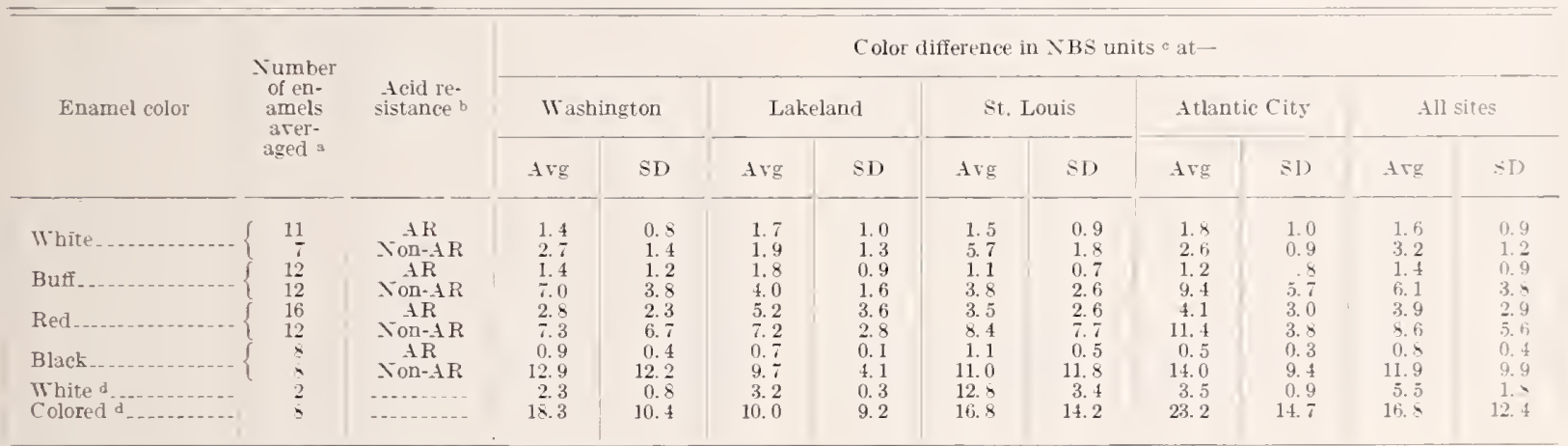

a Each enamel represented by two panels at each location.

b Grouped according to spot test of Porcelain Enamel Institute; A R uncludes class A A, A, and B enamels, Non-A R includes class C and D. arerage.

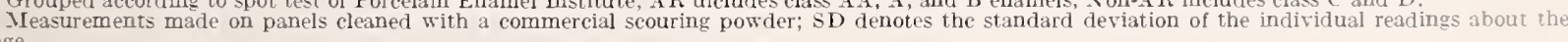

d Full-mat enamels; all others are glossy or semimat.

present, the conditions at Lakeland being more serere on the acid-resistant panels (class A A, A, and B) and the conditions at Atlantic City giving the most attack on the nonacid-resistant (class C and D) compositions. This order of severity is a reversal of the trend noted in the $7-\mathrm{yr}$ inspection [4]. The cause of the reversal is believed to be the difference in the cleaning procedures. 'The scouring treatment used at the $15-\mathrm{rr}$ inspertion removed surface films more effectively than the washing treatment used at the $7-\mathrm{yr}$ inspertion, and, in addition, scouring corresponds to commercial cleaning practice. Therefore, it is suggested that the 15 -rr results give a more realistic picture of the relative severity of the exposure ronditions at the four sites than do the $7-5 r$ data.

The greater severit $x$ of conditions at Lakeland on acid-resistant compositions is especially noticeable for some of the red enamels. For example, table 3 shows a color change at Lakeland of 10.6 NBS units for the enamel represented by panels $\mathrm{L}-21$ to $\mathrm{L}-28$, and 12.1 units for $\mathrm{L}-31$ to $\mathrm{I}-38$, ret the greatest color change for these same two compositions at any of the other sites was only 4.5) units. The cause of the greater changes in color' and gloss for acid-resistant enamels at Lakeland has not been determined, but it could be associated with (a) the higher values for annual sunshine, rainfall, and temperature, as giren in table 2. $01^{\circ}$ (b) the attack by organic acids produced by algae and fungi that were found to be attached on the surfaces of all panels at the Lakeland exposure site, and that were described in the cartiel paper [4]. Similar growths have been foumel by Jones [12] to canse etching of ecrtain optical glasses used in the tropies.

The sulfur dioxide content of the atmosphere at the St. Lonis site was found to be abone t5 times as great as in Washington [3]. yet table:? shows that, on the average, the $W_{\text {as shington panels }}$ were affected more by the 15-ro exposure than those at St. Louis. This could be cansed hy the heavier rainfall in Washington (sece table 2), but a more likely explanation is that the heary alecmmulation of dirt and grime on the panel surfites at St. Louis acted as a potective layer. Hat the st. Louis panels been thoroughly ileaned at periodic intervals, the attalek at $\leqslant$, "l andis might well have been greatly increased.

A statistical analisis. performed by 11 . . . Touden of the Applied Mathematies 1)irision at the National Burean of stamelarels. showed that 
the observed differences in behavior at the fou sites were statistically significant. The same analysis showed the presence of small but real differences $i n$ frits of the same type make by different manufacturers; however, there was no evidence of significant differences between enamels marle with the same frit by two fabricators.

\section{Laboratory Tests for Predicting Weather Resistance}

An acceptable test for predicting weather resistance should give a definite separation between the enamels that showed only minor deterioration after 15 ir of exposure and those that showed objectionable fading and loss of gloss. To determine whether or not the citric acid spot test would give such a separation, all of the enamels except the full mats were first given ratings of excellent, good, fair, or poor, depending on a combination of their measured gloss and color-change values. These ratings were then compared with the results of the citric acid spot test

The adjective ratings for the comparison were assigned $\mathrm{m}$ accordance with the following arbitrarily chosen criteria:

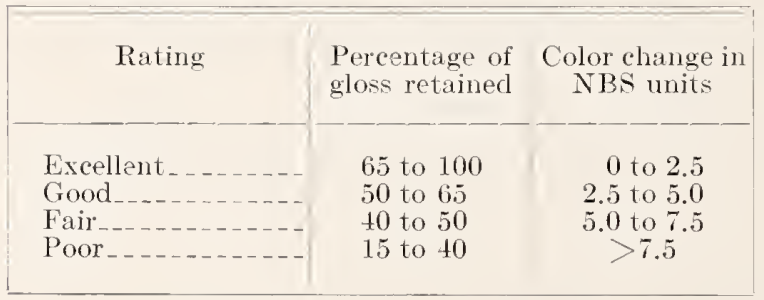

Enamels with values of gloss retained between 65 and 100 percent at all four sites were rated excellent only if the maximum color change dic not exceed 2.5 NBS units at any of the locations. If the values for either gloss or color change fell outside of these limits at any one of the four sites, the enamel was given the lowest applicable rating. For example, in table 3 the enamel represented by panels $\mathrm{P}-51$ to 58 would be rated excellent from the standpoint of gloss retained (lowest value 79.0), but the maximum color change at one of the test sites was 12.9 units. On the basis of color change alone this particular enamel is rated poor, in spite of its excellent gloss retention. Conversely, the white enamel represented by panels $\mathrm{C}-71$ to 78 shows a maximum color change of only 1.9 units; yet, because the percentage of gloss retained at Lakeland was as low as 33.0 , the enamel received a rating of poor.

'The effectiveness of the spot test in separating' enamels of varying weather resistance when rated in accordance with the aforementioned procedure is given in table 6 . The figures in parentheses give the number of red enamels included in the
TABLE 6. Number of enamels having weather-resistance ratings of excellent, good, fair, and poor when grouped according to the citric acid test

\begin{tabular}{|c|c|c|c|c|c|}
\hline \multirow{2}{*}{$\begin{array}{l}\text { Acid resistance } \\
\text { (PEI test) }\end{array}$} & \multirow{2}{*}{$\begin{array}{l}\text { Number } \\
\text { of enam- } \\
\text { els tested }\end{array}$} & \multicolumn{4}{|c|}{$\begin{array}{l}\text { Number of enamels with weather- } \\
\text { resistance rating of - }\end{array}$} \\
\hline & & $\begin{array}{l}\text { Excel- } \\
\text { lent }{ }^{a}\end{array}$ & Good a & Fair a & Poor a \\
\hline $\begin{array}{l}\mathrm{AA} \\
\mathrm{A} \\
\mathrm{B} \\
\mathrm{C} \\
\mathrm{D}\end{array}$ & $\begin{array}{r}29 \\
15 \\
3 \\
21 \\
18\end{array}$ & $\begin{array}{c}11(1) \\
1 \\
0 \\
0 \\
0\end{array}$ & $\begin{array}{c}16(5) \\
7(2) \\
0 \\
0 \\
0\end{array}$ & $\begin{array}{l}2(1) \\
3(2) \\
1 \\
2 \\
0\end{array}$ & $\begin{array}{c}0 \\
4(3) \\
2(2) \\
19(8) \\
18(4)\end{array}$ \\
\hline
\end{tabular}

a Figures in parentheses are number of red enamels included in the total. See text for procedure used in assigning ratings.

total. From these figures it can be seen that if the red enamels are eliminated from consideration, there are only three remaining cases in which an acid-resistance rating of $\mathrm{A}$ or $\mathrm{AA}$ did not correctly indicate a weather-resistance rating of good or better. 'Two of these three had fair weather' resistance.

The poor ratings of most of the red enamels of class $\triangle \mathrm{A}, \mathrm{A}$, and $\mathrm{B}$ acid resistance is a result of excessive color change. It should be pointed out that red enamels are pigmented with the so-called cadmium sulfo-selenide complexes. When such pigments are subjected to strongly oxidizing conditions, they are known to change color. 'Thus, if the surface of a red enamel were to become slightly etched during weathering, the exposed pigment particles would be expected to change in color if oxidizing influences were present. When the vitreous phase of the enamel initially surrounds and covers the particles of pigment completely, and is not subsequently etched away, the pigment is protected against the color change associated with oxidation. Correspondingly, a laboratory test, to correlate well with performance data, must provide a commensurate degree of etching, and for pigments that are highly sensitive to oxidation, also a commensurate degree of oxidizing potential. In this connection, McDonald [13] found that certain red screening enamels faded noticeably in 1 to 4 rears, although they showed class $\Lambda \mathrm{A}$ acid resistance by the citric acid spot test. He also found that a spot test with concentrated nitric acid, which is more corrosive and highly oxidizing; would distinguish the red enamels showing poor weather resistance from those that were resistant to fading.

Sweo [14] noted that a red semimat enamel of class $A$ acid resistance showed poor weatherability when exposed for 10 months. This same enamel gave a weight loss from 40 to 200 times greater than class $A$ enamels of good weather resistance when the specimens were subjected to a boiling solution of 6 -percent (by weight) citric acid for $2 \frac{1}{2} \mathrm{hr}$. Therefore, Sweo suggested that the boiling' citric acid test might be useful in predicting the suitability of enamels for exposure applications. 
Both the nitric acid spot test [13] and the boiling citric acid test [14] were used in the present inrestigation on storage panels of several of the red enamels. The correlation was somewhat better than the citric acid spot test, but neither test gave results that would predict the rather large color change found for enamels L-21 to 28 and $\mathrm{L}-31$ to $3 \mathrm{~S}$ at Lakeland. On the other hand, a treatment for $2 \frac{1}{2} \mathrm{hr}$ in a boiling aqueous solution of 10-percent (by weight) nitric acid did distinguish these two enamels from the acid-resistant reds that gave satisfactory weather resistance at all sites. Therefore, because of the promise shown br the boiling nitric acid test, all of the red enamels were subjected to this treatment.

The test was made on the 4-by 6-in. laboratory specimens. Each specimen was weighed to the closest milligram and then clamped to the ground face of a Prrex-brand glass tube of $21 \frac{1}{4}-\mathrm{in}$. inside diameter, a rubber gasket being used to prevent leakage. A reflux condenser was attached to the opposite end of the tube, and $70 \mathrm{ml}$ of the acid solution was added. The assembly was next placed on a hotplate with the back of the specimen in contact with the hot surface and the solution allowed to boil for $2 \frac{1}{2} \mathrm{hr}$. After removal from the hotplate, the specimen was cleaned by rubbing with a sponge wetted with a 1 -percent (by weight) solution of trisodium phosphate, rinsed in ethyl alcohol, air dried, and then reweighed, the change in weight being expressed as milligrams per square centimeter of exposed surface. In addition, the difference in color between the exposed and unexposed areas was measured, and the results expressed in NBS units.

Table 7 lists the results of the boiling nitric acid test for the 28 glossy and semimat red enamels included in the study. "The enamels are arranged in groups according to their weather resistance rating. The acid-resistance class by the citric acid spot test is given for purposes of comparison. It can be seen from this table that there are 5 enamels of class $A$ and $B$ acid resistance by the citric acid spot test that show unsatisfactory reathering behavior at 1 or more of the 4 exposure sites. These j enamels all gave weight losses greater than $1.0 \mathrm{mg} / \mathrm{cm}^{2}$. The 4 class A finishes with passable weather resistance (excellent, good, or fair) and all of the class AA enamels show weight losses of less than $1.0 \mathrm{mg} / \mathrm{cm}^{2}$. 'Thus, for' the red enamels included in this investigation, the weight change after $2 \frac{1 / 2}{2} \mathrm{hr}$ of boiling in 10 percent-by-weight nitric acid gave the desired separation between enamels of poor weather resistance and those that were considered passable.

The data in table 7 show that the measured color change after test is not as reliable a criterion as weight loss, because one enamel of good weather resistance $(\mathrm{P}-1$ to 8$)$ shows a fairly high color change (5.3 NBS units) after the nitric acid treatment, whereas one of the enamels of poor weather resistance ( $\mathrm{P}-51$ to 58 ) shows a color change of only 3.6 NBS units.
TABLE 7. Citric acid spot test and briling nitric acid, tast results for red enamels having escellent, good, fair, and porm weather resistaree

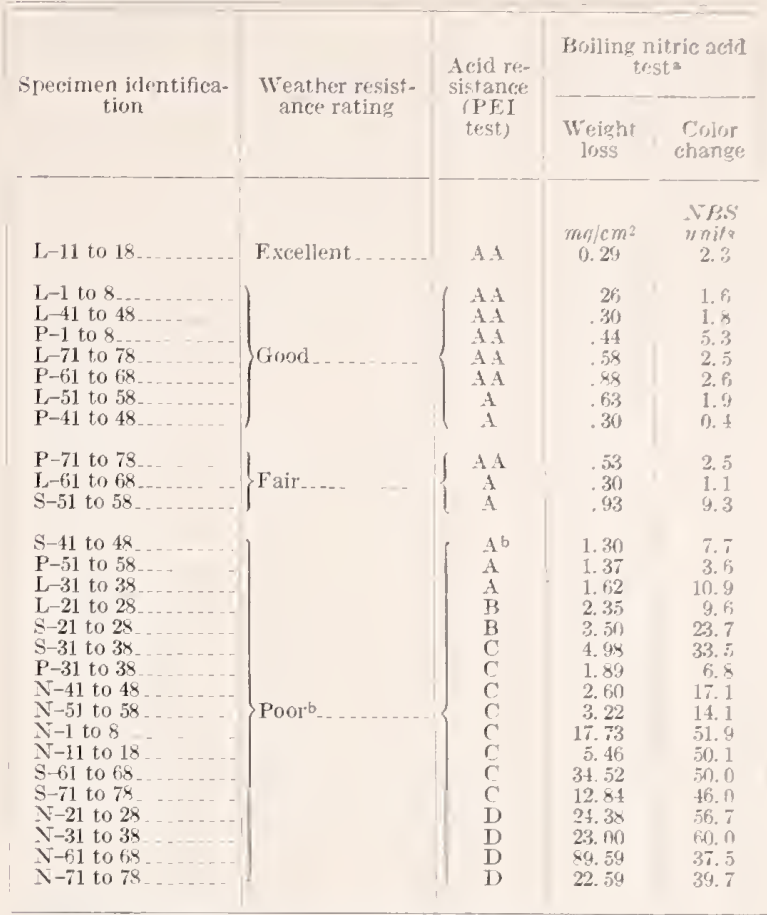

Measurements made on one specimen from each group.

Poor ratings of two of the three $A$ and one of the two assigned because of the large color changes noted at the Lakeland site.

\section{Discussion}

The four most important requirements of a porcelain enamel finish that is to be used for outside exposure are (1) corrosion protection, (2) color stability, (3) ease of cleaning, and (4) absence of major changes in initial gloss.

The results of the $15-\mathrm{yr}$ study show that colrosion protection on a steel base can be obtained with any of the enamels included if proper attention is given to initial coverage. Two coats of enamel should be applied to the back surfaces of all panels and to attachment lugs, exeept possibly for those installations where absence of moisture on the back surface of the panels can be assured for the life of the installation.

From observations made during the test. and from a study of the literature, the change in eolor with exposure is believed caused by three cticets. The first and most important effect is the slow leaching of soluble constituents from the struttural network of the enamel ghass. leaving belind a gel layer rich in silica. "The hydrated layer" usually assumes a lighter color thail the erivinal surface and gives a faded appearince to the paned. The layer is probably present on all enamels after long exposure, but only on the enameds of pool acid resistance does it become sufficiently thick after $15 \mathrm{y}$ to gire objectionable changes in color 
and gloss. It is significant that glass on long exposure shows this same type of gel formation at the surface $[15,16]$.

The second effect that can change the color of enamel glasses is solar radiation. Parmalee and Barger [17] found a distinct darkening of a certain whiteware glaze when exposed for 2 months to sunlight through a window, or when exposed for a few hours to radiation from either a quartz mercury arc or a carbon are. Tests made early in the present study [3] showed that there was no detectable change in color for any of the 14 types of enamel after $500 \mathrm{hr}$ of exposure to carbon arc radiation. Nevertheless, solar radiation striking the panels over a $15-\mathrm{yr}$ period could conceivably have an unfavorable effect. In fact, the greater color change for the acid-resistant red enamels at Lakeland, which had the highest annual sunshine, might have been caused, in part, by the effects of solar radiation.

The third factor that might affect color change is the oxidation of the pigment used for coloration. Most ceramic pigments are mixtures of oxides that are known to be chemically stable. The red and orange enamels, on the other hand, are normally pigmented with complexes formed from mixtures of cadmium, selcnium, and sulfur, whereas yellow enamels normally contain cadmium sulfide. Such compounds are sensitive to strong oxidizing agents. It is conceivable that a slow oxidation of these compounds could occur during exposure and thereby cause a color change. This effect would be most noticeable in enamels with high pigment concentrations, and especially in those cases where the particles of pigment at the surface were not properly covered by the enamel glass.

The ease of cleaning of enamel surfaces after long exposure is one feature of an enamel finish that holps to make it popular both for signs and for architectural installations. All enamels, with the exception of those with a full-mat finish (see footnote 3), clean easily when first installed. As exposure time increases, however, the finishes of poor acid resistance become etched and cleaning becomes more difficult. After $15 \mathrm{yl}^{\circ}$ of exposure, wide differences in cleanability were noted between acid-resistant and nonacid-resistant compositions, the surfaces with poor acid resistance being more difficult to clean. At the two sites where there was little atmospheric contamination by soot particles (Washington and Lakeland), cleaning was not a problem even on those finishes that had become etched during weathering.

The four exposure sites selected for the tests have fairly high annual rainfalls (see table 2 ). Moisture is essential to the formation of the gel layer mentioned earlier; therefore, in a dry climate, weathering would be expected to proceed at a slower rate than at Washington, Lakeland, St. Louis, or Atlantic City. Likewise, in an area of extremely heavy rainfall the weathering action would undoubtedly be accelerated.
The direct relation between the acid resistance of an enamel finish and its resistance to weathering is evident in tables 3,4 , and 5 . These results are in agreement with the findings of the eartier inspections on the same panels $[3,4]$; also with conclusions of other investigators $[14,18,19$, $20,21,22]$.

The citric acid spot test might be considered as a reasonably satisfactory laboratory test for gaging weather resistance if the correlation was as good for the red enamels as for the other types. However, the farling of the red finishes cannot be predicted with certainty by the citric acid spot test; hence for red enamels it should be supplemented with a second treatment that provides strongly oxidizing conditions. The boiling $10-$ percent nitric acid test appears to fulfill this requirement.

In the present study, all panels were exposed at a $45^{\circ}$ angle. This type of exposure would be expecter to give a more rapid weathering of the cnamel than if the same enamel were exposed on a sheltered vertical wall. It is significant that even under the severe conditions of $45^{\circ}$ exposure, the enamels with class $\mathrm{AA}$ acid resistance by the PEI test showed only small changes in gloss and color after the 15-rr exposure period.

\section{Recommendations}

On the basis of the 15 -rr data the authors feel justified in making the following recommendations:

1. When the enamel is applied to an iron or low-carbon-steel base, at least two coats of enamel should be applied to the back surface so as to insure good coverage of the metal and prevent damage from corrosion. Good coverage on the face side is an obvious requirement

2. Only enamels of class A and class AA acid resistance (PEI test) should be used in any architectural installation where general appearance, absence of fading, and ease of cleaning are important. In ardition, when the color of the enamel is red, orange, or vellow, only those enamels should be selected that will give a weight loss of less than $1.0 \mathrm{mg} / \mathrm{cm}^{2}$ when subjected to a solution of boiling 10 -percent nitric acid for $2 \frac{1}{2} \mathrm{hr}$.

3. Where appearance is an important factor, full-mat enamels of the trpe inclurled in this investigation should not be used for outside installations, as ther tend to accumulate and retain a dirt film. In addition, the colored fullmat enamels fade after short exposure periods.

4. New enamel types, and especially those prepared from screening pastes, should be tested for weather resistance as they are developed to determine whether or not ther show the same correlation between acid resistance and weather resistance that was shown by the enamels included in this study. This correlation could be establisherl in periods of considerably less than $15 \mathrm{yr}$. 


\section{Summary}

An examination of 7841 -ft-square porcelain enameled panels of varying types was made after approximately $15 \mathrm{rr}$ of exposure at Washington, D. C.. Lakeland, Fla., St. Louis, Mo., and Atlantie City, $\mathbf{X}$.J. The observations made after this examination mar be summarized as follows.

1. Ease of cleaning was related to weather rosistance. the enamels showing large losses in gloss being more difficult to clean than those that showed only minor losses.

2. All enamels successfully protected the steel base from corrosion when initial coverage was complete.

3. Poor corerage on the backs of panels resulted in spalls on the face surface at 3 of the 4 locations after 15 rr of exposure.

t. Based on gloss and color-difference measurements on panels cleaned by scouring, the exposure conditions at Lakeland were found to be somewhat more serere on the enamels of high acid resistance whereas the conditions at Atlantic City were slightly more severe on the nonacid-resistant compositions.

5. A direct relationship was found between acirl resistance as measured by the citric acid spot test and weather resistance as measured by changes in gloss and color, except that some of the red enamels of good acid resistance showed excessive fading after 15 ir of exposure at Lakeland.

6. A test that involved exposure of red enamels to a boiling solution of 10 -percent nitric acid for $2{ }^{3 / 2} \mathrm{hr}$ was found to give a separation of the compositions that faded from those that had superior resistance to fading.

7 . The best of the enamels showed no objectionable changes in either color or gloss at any of the foul exposure sites.

The assistance of the Porcelain Enamel Institute in the financing of the installation of the panels is gratefully acknowledged; also, the help of 'Thomas Robusto, Charles Brubaker, and John Anderson of the Bureau staff, who assisted in making the gloss- and color-difference measurements, and of Gerald Galler, who performed the tests with boiling nitric acid.

The investigation was made possible by the cooperation of the following companies, which supplied the necessary enamel frits and specimens:

Baltimore Enamel \& Novelty Co.

IV. A. Barrows Porcelain Enamel Co.

Chicago Vitreous Corporation

Daridson Enamel Products Co.

Erie Enameling Co.

Ferro Enamel Corp.

General Porcelain Enameling \& Mfg. Co.

Ingram-Richardson Mfg. Co.
Penco Corp.

Porcelain Metals Corp.

Poreelain Products Co.

Seaporcel Corp.

J. M. Seasholtz \& Sons

Texlite, Inc.

Toledo Porcelain Enamel Produets Co.

Wolverine Porcelain Enameling Co.

\section{References}

[1] Proceedings of Conference on Porcelain Enamel in the Building Industry, Research Conf. Report $\$ o$. 6 of Building Research and Advisory Board, Tational Academy of Sciences (National Tiesearch Council, 2101 Constitution Ave., Washington 25, D. C., March 1954).

[2] Proceedings of Conference on Architectual Porcelain Enamel (Porcelain Enamel Institute, $11+5$ 19th St., N. W., Washington 6, D. C., March 19.5.)

[3] W. N. Iarrison and D. G. Moore, Meather resistance of porcelain-enameled iron structural units, J. Pe-

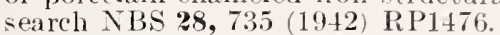

[4] W. N. Harrison and D. G. Moore, Weather resistance of porcelain enamels exposed for seven years, J. Pesearch NBS 42, 43 (1949) RP1949.

[5] F. J. Norton, Diffusion of $\mathrm{D}_{2}$ from $\mathrm{D}_{2} \mathrm{O}$ through steel, J. Appl. Phys. 24, 499 (1953)

[6] C. A. Zapffe and C. E. Sims, Relation of defect in enamel coatings to hydrogen in steel, J. Am. Ceram. Soc. 23, $192(1940)$.

[7] R. S. Hunter, A multipurpose photoelectric reflectometer, J. Research NBS $\mathbf{2 5}, 581$ (1940) RP1345.

[8] D. G. Moore and R. S. Hunter, Use of liquid surfaces as standards of specular gloss, J. Am. Ceram. Soc. 24, $167(19+1)$.

[9] R. S. Hunter, Photoelectric color-difference meter, J. Opt. Soc. Amer. 35, 661 (1948)

[10] R. S. Hunter, Photoelectric tristimulus colorimetry with three filters, NBS Circ. $429(19+2)$

[11] Deane B. Judd, Color in business, science and industry, John Wiley \& Sons, Inc., New lork, $\searrow$. (1952).

[12] F. L. Jones, Deterioration of glass in tropical use J. Am. Ceram. Soc. 28, $32(1945)$

[13] E. F. IIcDonald, Comments on paper on weather resistance, Proceedings of Conference on Architectural Porcelain Enamel, p. 44 (Porcelain Enamel Institute, 1145 19th St., $工$. IV., Washington 6 . D. C., March 1955).

[14] B. J. Sweo, Correlation of weather resistance of porcelain enamels with chemical test data. J. An. Ceram. Soc. 32, 333 (1949).

[15] A. W. Laubengayer, The weathering and iridescence of ancient Roman glass found in Cyprus, J. Am. Ceram. Soc. 14, 833 (1931).

[16] J. W. Wellor, The durability of glazes, olswes and enamels in service, Trans. Eng. Cermm. Soc. 34. 113 (1934).

[17] C. W. Parmelee and A. E. Bitdger, Notes on the coloration of glazes by light, J. Am. Cermm. Soc. 13. $1(1934)$.

[18] M. G. Ammon, Exposure tests on arehitectural porcelain enamels, Enamelist 16, 7 (19:36)

[19] B. J. Sweo, Progress report on weathering tests architectural enamels, Enmmelist 18,13 ( $14-40)$

[20] J. C. Hudson and T. i. Binfield, The pretection of steel by rarious non-metallie coating:. J. l hon sterel Inst. 158, 99 (1948).

[21] Anonymous, Weather resistance of mamels. Cilsh Email-Kieramo-Tech 6, 2:3 (1955).

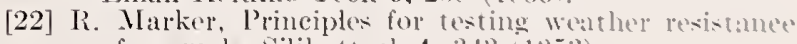
of emamels, Silikattech $4,34:(1953)$.

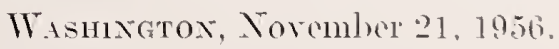



[Continued from cover page II]

BMS37

B.MS38

BMS39

BMS40

BMS41

BMS42

BMS43

BMS44

BMS45

BMS46

BMS47

BMIS48

BMS49

B.IS50

BMS51

BMS52

BMS53

BMS54

BMS55

BMS56

BMS57

BMS58

BMS59

BMS60

BMS61

BMS62

BMS63

BMIS64

BMS65

BIIS66

BMS67

BMS68

BMS69

BMIS70

BIIS71

BIIS72

BMS73

BMIS74

BMS75

BMS76

BMS77

BMS78

BMS79

BMS80

BMIS81

BMS82

BMS83

BMS84

BMS85

BMS86

BMS87

-Out of print.
Structural Properties of "Palisade Homes" Constructions for Walls, Partitions, and Floors Sponsored by Palisade Homes. Dunn Manufacturing Co
Structural Properties of a Wall Construction of "Pfeifer Units" Sponsored by the Wisconsin Units Co by Knap America, Inc

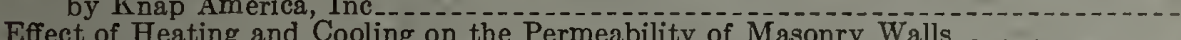
Structural Properties of Wood-Frame Wall and Partition Construction with "Celotex" Insulating Boards Sponsored by The Celotex Corporation Performance Test of Floor Coverings for Use in Low-Cost Housing: Part 2 Surface Treatment of Steel Prior to Painting . Air Infiltration Through Windows

Structural Properties of "Scott-Bilt" Prefabricated Sheet-Steel Construction for Walls, Floors, and Roofs Sponsored by The Globe-Wernicke Co

Structural Properties of Prefabricated Wood-Frame Constructions for Walls, Partitions, and Floors Sponsored by American Houses, Inc .

tions, and Floors Sponsored by American Houses, Inc

Sponsored by the Homasote Co
Metallic Roofing for Low-Cost House Construction

Stability of Fiber Building Boards as Determined by Accelerated Aging.

Structural Properties of "Tilecrete Type A" Floor Construction Sponsored by the Tilecrete Co

Effect of Ceiling Insulation Upon Summer Comfort

Structural Properties of a Masonry Wall Construction of "Munlock Dry Wall Brick"
Sponsored by the Munlock Engineering Co Sponsored by the Munlock Engineering Co
Heating Boiler

Effects of Wetting and Drying on the Permeability of Masonry Walls.

A Survey of Humidities in Residences.

Roofing in the United States-Results of a Questionnaire-

Strength of Soft-Soldered Joints in Copper Tubing . .

Properties of Adhesives for Floor Coverings Bricks Produced in the United States.

Structural Properties of Two Nonreinforced Monolithic Concrete Wall Constructions--

Structural Properties of a Precast Joist Concrete Floor Construction Sponsored by the Portland Cement Association

Moisture Condensation in Building Walls

Solar Heating of Various Surfaces- Walls

Methods of Estimating Loads in Plumbing Systems

Plumbing Manual

Structural Properties of "Mu-Steel" Prefabricated Sheet-Steel Constructions for Walls, Partitions, Floors, and Roofs, Sponsored by Herman A. Mugler.-

Performance Test for Floor Coverings for Use in Low-Cost Housing: Part 3

Stability of Fiber Sheathing Boards as Determined by Accelerated Aging - .

Asphalt-Prepared Roll Roofings and Shingles._.

Fire Tests of Wood- and Metal-Framed Partitions struction Sponsored by the Homasote Co

Indentation Characteristies of Floor Coverings

Structural and Heat-Transfer Properties of "U. S. S. Panelbilt" Prefabricated SheetSteel Constructions for Walls, Partitions, and Roofs Sponsored by the Tennessee Coal, Iron \& Railroad Co

Survey of Roofing Materials in the North Central States

Effect of Outdoor Exposure on the Water Permeability of Masonry Walls......

Properties and Performance of Fiber Tile Boards

Structural, Heat-Transfer, and Water-Permeability Properties of Five Earth-iVall Constructions

Water-Distributing Systems for Buildings.

Performance Test of Floor Coverings for Use in Low-Cost Housing: Part 4 -

Field Inspectors' Check List for Building Constructions (cloth cover $5 \times 71 / 2$ inches) - -

Water Permeability of Walls Built of Masonry Units

Strength of Sleeve Joints in Copper Tubing Made With Various Lead-Base Solders..-

Durvey of Roofing Materials in the South Central States.Temperature.

Structural Heat-Transfer, and Water-Permeability Properties of "Speedbrik" Wall

Construction Sponsored by the General Shale Products Corporationcommittee on Specifications of the Central Housing Committee on Research, Design, and Construction.

[List continued on cover page IV]

\section{$10 \notin$} $10 \%$ 


\section{BUIIDING MATERIALS AND STRUCTURES REPORTS}

\section{[Continued from cover page III]}

BMS88

BMS89

BMS90

BMS91

BMS92

BMS93

BMS94

BMS95

BMS96

BMS97

BMS98

BMS99

BMS100

BMS101

BMS102

BMS103

BMS104

BMS105

BMS106

BMS107

BMS108

BMS109

BMS110

BMS111

BMS112

BMS113

BMS114

BMS115

BMS116

BMS117

BMS118

BMS119

BMS120

BMS121

BMS122

BMS123

BMS124

BMS125

BMS126

BMS127

BMS128

BMS129

BMS130

BMS131

BMS132

BMS133

BMS134

BMS135

BMS136

BMS137

BMS138

BMS139

BMS140

BMS141

BMS142

BMS143

BMS144

BMS145

BMS146

BMS147

BMS148

BMS149

BMS150

Recommended Building Code Requirements for New Dwelling Construction With Special Reference to War Housing Wood-Frame Wall Construction Sponsored by the Homasote Co_.......... Structural Properties of "PHC" Prefabricated Wood-Frame Constructions for Walls, Floors, and Roofs Sponsored by the PHC Housing Corporation........ A Glossary of Housing Terms Fire-Resistance Classifications of Building Constructions Accumulation of Moisture in Walls of Frame Construction During Winter Exposure "Knap Concrete-Unit" Walls Tests of Cement-Water Paints and Other Waterproofings for Unit-Masonry Walls.-.Properties of a Porous Concrete of Cement and Uniform-Sized Gravel. Experimental Dry-Wall Construction With Fiber Insulating Board.

Physical Properties of Terrazzo Aggregates

Structural and Heat-Transfer Properties of "Multiple Box-Girder Plywood Panels" for Walls, Floors, and Roofs

Relative Slipperiness of Floor and Deck Surfaces

Strength and Resistance to Corrosion of Ties for Cavity Walls

Painting Steel _.

Measurements of Heat Losses From Slab Floors Partitions, Floors, and Roofs Sponsored by the Douglas Fir Plywood Association.

Paint Manual with particular reference to Federal Specifications

Laboratory Observations of Condensation in Wall Specimens

Building Code Requirements for New Dwelling Construction

Temperature Distribution in a Test Bungalow With Various Heating Devices -

Paints for Exterior Masonry Walls

Performance of a Coal-Fired Boiler Converted to Oil

Properties of Some Lightweight-Aggregate Concretes With and Without an AirEntraining Admixture

Fire Resistance of Structural Clay Tile Partitions

A Study of a Baseboard Convector Heating System in a Test Bungalow . . .

Preparation and Revision of Building Codes

Fire Resistance of Walls of Lightweight Aggregate Concrete Masonry Units.

Stack Venting of Plumbing Fixtures-

Wet Venting of Plumbing Fixtures

Fire Resistance of Walls of Gravel-Aggregate Concrete Masonry Units

Investigation of Failures of White-Coat Plasters

Physical Properties of Some Samples of Asbestos-Cement Siding

Fire Tests of Wood-Framed Walls and Partitions With Asbestos-Cement Facings.--

Fire. Tests of Steel Columns Protected With Siliceous Aggregate Concrete-_...-...-

Stone Exposure Test Wall

The Self-Siphonage of Fixture Traps

Effect of Aging on the Soundness of Regularly Hydrated Dolomitic Lime Putties..-

Atmospheric Exposure Tests of Nailed Sheet Metal Building Materials . . .......-...-

Fire Endurance of Shutters for Moving-Stairway Openings

Methods and Equipment for Testing Printed-Enamel Felt-Base Floor Covering.-.-

Fire Tests of Gunite Slabs and Partitions

Capacities of Plumbing Stacks in Buildings.

Live Loads on Floors in Buildings

Fire Resistance of Concrete Floors

Fire Tests of Steel Columns Encased With Gypsum Lath and Plaster-1.....-

Properties of Cavity Walls.

Influence of the Wash From Bronze on the Weathering of Marble Floors Studies of Stone-Setting Mortars Second Edition, Selected Bibliography on Building Construction and Maintenance-.Ceilings

Frost Closure of Roof Vents.

Fire Tests of Brick Walls

Sound Insulation of Wall and Floor Constructions

Fire Effects and Fire Control in Nitrocellulose Photographic-Film Storage.......... Plasticity and Water Retentivity of Hydrated Limes for Structural Purposes Effects of Mineral Additives on the Durability of Coating-Grade Roofing Asphalts..Fifteen-Year Exposure Test of Porcelain Enamels Combustible Contents in Buildings._.

Methods of Testing Small Fire Extinguishers "Out of print. 